\title{
Mobility in the Atacama Desert, northern Chile, in the Late Intermediate Period (AD 900-1450): A re-evaluation using stable isotope analysis
}

\author{
Francisca Santana-Sagredo ${ }^{a^{*}}$, Julia Lee-Thorp ${ }^{a}$, Rick Schulting $^{a}$, Mauricio Uribe $^{b}$
}

\author{
${ }^{a}$ Research Laboratory for Archaeology and the History of Art, University of Oxford, 1 South \\ Parks Road, Oxford OX1 3TG, UK.

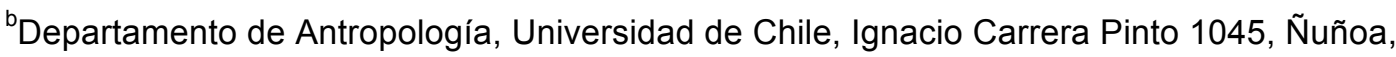 \\ Santiago, Chile. \\ *Corresponding author. E-mail address: francisca.santanasagredo@arch.ox.ac.uk
}

\section{Abstract}

Research on the Late Intermediate Period (AD 900-1450) in northern Chile has been strongly influenced by two mobility models: John Murra's classic vertical ecological archipelago model, with highland colonies in the lowlands; and the gyratory mobility model, with pastoralists and their llama caravans controlling trade. The widespread application of these two models, however, suffers from a lack of supporting archaeological evidence. Stable isotope analysis provides a more direct approach for studying both diet and mobility patterns, complementing material culture studies. The aim of this paper is to evaluate the presence of colonies and specialized highland caravans in the lowlands of northern Chile through the application of $\delta^{13} \mathrm{C}, \delta^{15} \mathrm{~N}$ and $\delta^{18} \mathrm{O}$ to human tooth enamel, bone collagen and bone apatite. The results show strong local traditions in terms of diet and mobility associated with the Loa-San Pedro, Antofagasta and Pica-Tarapacá cultural groups. Our results suggest a non-local origin for some individuals in Pica-Tarapacá and Loa-San Pedro, but provide little evidence to support either the presence of 'colonies' or of specialized 'caravans'. Mobility patterns were, instead, diverse and flexible, including female and male individuals that moved at different moments of their lives.

Keywords: stable isotopes, mobility, palaeodiet, Atacama Desert 


\section{Introduction}

The Late Intermediate Period or LIP (AD 900-1450) was characterised by a high degree of independence and autonomy amongst the diverse cultural groups inhabiting the South Central Andes, including the Atacama Desert. Even though there was no central state, these groups maintained long-distance connections amongst themselves, which appear to have increased through time based on the presence of goods from different regions (Núñez, 1984; Pimentel, 2012). It has been proposed that the main driving force behind these connections was the exchange of goods, specifically prestige objects (i.e. textiles, non-local pottery, metals) and foodstuffs.

Different models propose mobility in the form of colonies or caravans to account for the evidence of trade and movement of materials from different regions, based on ethnohistorical and ethnographical records, sometimes combined with the archaeological evidence (Murra, 1972; Núñez, 1984; Núñez and Dillehay, 1995). The archaeological record generally supplies only indirect evidence, such as foreign and/or exotic objects in local sites, usually cemeteries (Núñez, 1984; Núñez and Dillehay, 1995) or along ancient routeways and at the logistic inter-nodal sites associated with them (Pimentel, 2012). However, the presence of non-local objects such as pottery or textiles does not necessarily mean the presence of individuals coming from somewhere else, nor do they by themselves imply colonies or caravans. Therefore, it is still not clear how satisfactory these models are, and whether human mobility occurred in the ways and for the reasons proposed, i.e., as part of an integrated economic system.

Radiogenic strontium and stable $\delta^{18} \mathrm{O}$ isotopes are frequently applied as indicators of mobility in the sense that birth and burial place may differ (Bentley, 2006; Knudson et al., 2007; Knudson, 2009). However, diet also provides evidence for mobility because foodways are a culturally mediated practice that migrants may have carried with them. In this paper we concentrate on the study of human diet and mobility at the individual 
level in the Atacama Desert using stable carbon, nitrogen and oxygen isotopes for the Loa-San Pedro, Antofagasta and Pica-Tarapacá cultural groups, evaluating and contrasting our results with the mobility models mentioned before.

\section{Regional setting: The Atacama Desert}

The dynamics that characterise how ancient populations lived and moved through the landscape are intrinsically related to local geography. The Atacama Desert is the driest desert in the world. It occupies an area extending from southern Peru $\left(18^{\circ} \mathrm{S}\right)$ to northern Chile $\left(27^{\circ} \mathrm{S}\right)$ (Latorre et al., 2003; Latorre et al., 2005). Rainfall is almost nil between 0-2000 masl, occurring sporadically and reaching values between 0.6-10 mm per annum (Aravena et al., 1999). Precipitation increases with altitude in the Andean Cordillera, coming not from the Pacific but from the Amazon Basin and Atlantic Ocean (Aravena, 1995; Aravena et al., 1999).

Various geographical zones characterise the study area (Troll, 1958) (Fig. 1). The coastal fringe and the adjacent Coastal Cordillera ( 0 masl) is characterized by a very long, narrow plain, in which vegetation is highly adapted to dry environments and terrestrial faunal diversity is low (Marquet et al., 1998). The main resources associated with the coast are the rich marine fauna of the Pacific Ocean (Camus, 2001). The pampa lies between the Coastal Cordillera and the pre-cordillera area at an altitude of 900-2000 masl and is characterized by an expansive plateau (Gutierrez et al., 1998). It is the most arid area in the Atacama Desert; rainfall is almost non-existent and vegetation is scarce (Aravena, 1995; Latorre et al., 2005). However, groundwater systems and springs, together with the Loa River - the only river that crosses the desert from the Andes to the ocean in the study area - make possible the presence of vegetation and fauna, including the extensive forest Pampa del Tamarugal, as well as human occupation. Above the pampa lie valleys and depressions of the pre-cordilleran quebradas and finally the altiplano and highlands of the Andean Cordillera, from about 2500 masl up to 6000 masl (Troll, 1958; Latorre et al., 2003; Latorre et al., 2005). This 
is the only zone with reliable precipitation, and so presents a wider range of flora and fauna species.

\section{Archaeological traditions of the Atacama Desert during the LIP}

\subsection{Antofagasta}

The communities inhabiting the coast of Antofagasta during the LIP maintained a strongly marine tradition with roots in the Archaic period, from ca. 8000 years BP (Ballester et al. 2014; Ballester and Clarot, 2014; Andrade et al., 2015). The archaeological evidence emphasises fishing-related material culture, including hooks, stone sinkers, harpoons, spears and leather for raft construction. Inland contacts occurred, as inferred from the presence of pottery, textiles, plants and wooden tables for hallucinogen consumption in funerary contexts, although their frequency is low (Ballester and Clarot, 2014).

\subsection{Loa-San Pedro}

At the San Pedro de Atacama oases (2400 masl), the LIP has been defined largely as a period of crisis after the Tiwanaku collapse (Costa-Junqueira, 1988; Schiappcasse et al., 1989; Knudson and Torres-Rouff, 2009; Uribe, 2012). Nevertheless, the LIP here shows new cultural dynamics that led local populations to interact with the highlands in the Upper Loa River (pre-cordillera) and altiplano communities as far as southern Bolivia and northwest Argentina (Uribe, 2012). Furthermore, agricultural activities reached high levels of specialization. In the San Pedro oases, agriculture activities were carried out next to the rivers San Pedro and Vilama, as in previous periods (Núñez, 1995) but terracing and canals expanded to the higher quebradas of the Atacama Basin and the Upper Loa River (Uribe, 2012). Beans, maize, squash, and other domestic crops were grown but were complemented with 'wild' fruits such as algarrobo (Prosopis algarrobo) and chañar (Geoffroea decorticans) (Núñez, 1995). Zooarcheological evidence suggests a heavy reliance on camelids and pastoralist 
activities (Núñez, 1995). Evidence for coastal contacts, by contrast, is scarce (Núñez, 1984; Núñez, 1995; Uribe 2012).

\subsection{Pica-Tarapacá}

The Pica-Tarapacá culture occupied the driest area of the Atacama Desert, including the arid coast, Pampa del Tamarugal (valleys and oases) and the sierra or precordillera. In each of these zones, different economic specializations were developed, with fishing, hunting and gathering of marine resources in the coastal region, and intensive agriculture in the valleys, highlands and altiplano (Núñez, 1984; Uribe, 2006). These specializations contributed to the exchange of resources, generating multiple systems of economic complementarity and social interaction (Moragas, 1995; Uribe, 2006). Even though each zone had its own economic activities, the Pica-Tarapacá communities shared strong connections based on their material culture, such as pottery and textiles with a local style that can be clearly differentiated from those of other contemporaneous cultural groups (Uribe, 2006).

\section{Mobility models in northern Chile during the LIP: advances, limitations and} new perspectives

The LIP represents a period of local development in which the basic social structure has been related to the Andean ayllu, a particular mix of clans and tribes known from the ethnohistoric period. The ayllus were based on strong social dynamics of reciprocity and redistribution between individuals and families (Uribe, 2006; Nielsen, 2009). These antecedents led Murra (1972) to propose his classic model of the 'maximum control of ecological vertical archipelagos'. Given the particular geography that characterises the Andes (coast, valleys, highlands, altiplano, and the Amazon), the groups inhabiting the different ecological zones produced products not available in other zones, promoting trade between them. Murra went further, proposing that these 'ecological archipelagos' took the form of colonies under the control of altiplano 
chiefdoms, which therefore gained direct access to, and control of, the resources they lacked. It is therefore a model of sociopolitical organization as well as of the economy. Núñez and Dillehay (1995) suggested that interaction occurred in a rather different way for the South Central Andes. Their 'gyratory mobility' (movilidad giratoria) model proposes that specialised pastoralist (from the highlands and altiplano) groups controlled the trade of objects between the ecological zones using llama caravans. The caravans could travel for many days or months, stopping at logistic camps for rest, water and food, moving between the settlements of other ethnic groups along the altitudinal gradient from the Andes to the coast. Núñez and Dillehay (1995) proposed that 'gyratory mobility' (or caravan activity) could be identified in the archaeological record when specific non-local objects are present in residential sites, cemeteries and/or inter-nodal sites. Based on ethnographic data, it has also been proposed that caravans groups would be composed mainly of men (Nielsen, 2009; Pimentel, 2012; Torres-Rouff et al 2012).

Both models concentrate exclusively on the altiplano or specialist highlands communities as the active participants, leaving the lowland communities and other groups as passive recipients, inactive in the exchange network, contacts and mobility. For example, scholars have discussed mobility patterns along the Pacific coast (Bittman, 1983; Rostworowski, 1989), but few have considered inland movements by coastal people (Pimentel, 2012). In this regard, Pimentel (2012) suggests two types of mobility patterns. The first is described as caravan mobility and routes that connected oases of the Atacama Desert between them and also with the coast through a complex road system. The second is coastal logistic mobility, in which individuals from the Pacific shore moved inland, following specific routes in order to obtain raw material for the manufacture of fishing equipment. Pimentel's (2012) work on the inter-nodal sites provides new perspectives on the mobility patterns for the area. Nevertheless, this study again concentrates on routes, inland caravan activity, and the materials involved in the exchange itself. 
These models still leave unanswered questions. First, to which cultural groups do the specialised agro-pastoralists belong (the altiplano or highlands?), or they were instead independent and constantly mobile caravans? Furthermore, what was their relation with the different local communities and how would they interact with them (Berenguer, 2004; Nielsen, 2009)? It is also not specified if the caravans primarily facilitated the exchange of resources for the altiplano colonies, or if they were totally independent during the LIP. Perhaps most importantly, while the presence of foreign objects in a local site implies trade or exchange, it does not necessitate that it occurred via specialised merchants or colonies who controlled all trade across zones, and/or that they actually inhabited these sites. Hence, we still lack insights as to whom was moving, and how and why they moved. The socio-economic connotations of their relations with the local communities remain unclear.

Núñez (1984) proposed that colonies would have kept their dietary traditions even in foreign locations. If so, one would expect to see a considerable number of individuals having a typical altiplano diet (i.e. terrestrial- $\mathrm{C}_{3}$ based diet) in the lowlands. The caravan model also carries the expectation of male individuals exhibiting a highland or altiplano diet, but these should be identifiable as outliers when buried in the cemeteries of coastal and valley populations, and should also be marked by distinct material culture, since there would presumably be no attempt to assimilate into the local community (Núñez and Dillehay, 1995). Characterising dietary and mobility patterns of individuals within local cultural groups will provide a better understanding of the economy and exchange systems. We assess the two models discussed above using carbon, nitrogen and oxygen isotope analyses of teeth and bone during the LIP for the Antofagasta, Loa-San Pedro and Pica-Tarapacá cultures.

\section{Stable isotope analysis background}


Diet reconstructions are based on the application of carbon and nitrogen stable isotopes. Both isotopes are measured using the delta notation $(\delta)$ in relation to the international standards VPDB for carbon and AIR for nitrogen (Sharp, 2007). Carbon isotopes distinguish between plants based on their photosynthetic pathway, which can be $C_{3}, C_{4}$ or CAM (Farquhar et al., 1989). In $C_{3}$ photosynthesis greater discrimination against ${ }^{13} \mathrm{C}$ occurs, leading to more negative $\delta^{13} \mathrm{C}$ values of ca. $-27 \%$. $\mathrm{C}_{4}$ plants discriminate less against the heavier isotope, leading to less negative $\delta^{13} \mathrm{C}$ values of ca. $-12 \%$. Carbon isotopes also differentiate between terrestrial $C_{3}$-based and marine diets, since marine systems are relatively enriched in ${ }^{13} \mathrm{C}$, though not to the extent of $\mathrm{C}_{4}$ plants. Thus, it can be difficult to differentiate between the consumption of marine and $\mathrm{C}_{4}$ resources.

Carbon from dietary protein will preferentially be routed to bone collagen, the organic fraction of bone (Ambrose and Norr, 1993). However, the inorganic fraction of bone and enamel, bioapatite, will instead reflect the overall diet consumed by an individual, since it receives its carbon composition from proteins, carbohydrates and lipids (Ambrose and Norr, 1993). By using the organic and inorganic fractions for isotope analysis, problems associated with the overlap of values between $\mathrm{C}_{4}$ and marine resources can be at least partly addressed. While both are ${ }^{13} \mathrm{C}$-enriched, diets emphasising $\mathrm{C}_{4}$ plants will be even more enriched than is possible with marine diets. Thus, apatite $\delta^{13} \mathrm{C}$ ratios above ca. $-7 \%$ are indicative of high $\mathrm{C}_{4}$ resource consumption (Santana-Sagredo et al., 2015). The interpretation of intermediate values remains problematic.

Considering the excellent preservation of tissues in the hyper-arid conditions of he Atacama Desert, it is unlikely that diagenesis affects bone mineral (Santana Sagredo et al., 2015). Bone apatite tends to preserve well under extreme arid conditions, being 
useful for isotope analysis and radiocarbon dating, even in the fossil record for the former (Lee-Thorp and Sponheimer 2003; Zazzo, 2014)

Nitrogen isotopes are firstly assimilated from the atmosphere and soil by plants. Then they are incorporated through diet to the protein composition of animals and humans. An increase in $\delta^{15} \mathrm{~N}$ of $2-6 \%$ occurs between prey and consumer in each trophic level (Schoeninger and DeNiro, 1984; Sponheimer et al., 2003). Marine fauna will tend to show higher nitrogen isotopes values due to the longer food chains in the sea, compared to terrestrial ecosystems (Schoeninger and DeNiro, 1984). However, $\delta^{15} \mathrm{~N}$ values can also be affected by a number of other factors including aridity, the use of fertilisers, amount of rainfall and elevation, and herbivore gut physiology (Heaton, 1987; Ambrose 1991; Sponheimer et al., 2003; Szpak et al., 2012).

Oxygen isotopes can be used for studying residential mobility (e.g. Knudson, 2009). The technique is based on the assumption that oxygen isotope values of bone or enamel apatite should reflect the isotopic composition of the water consumed by the individual in the period during which the tissue (bone or enamel) was formed (Knudson, 2009). All things being equal, the $\delta^{18} \mathrm{O}$ values of meteoric water decrease in a predictable fashion with distance from the source of water vapour and with elevation. Other environmental factors include temperature at the source and evaporation rates at the destination (Dansgaard, 1964; Sharp, 2007).

\section{Materials and Methods \\ 6.1 Sampling}

Bone collagen and apatite for a total of 102 individuals were analysed for this study along with a subset of 37 tooth enamel samples (Table 1). Only second and third molars, and in some cases premolars, were sampled in order to avoid complications with nursing effects (Knudson, 2009). All individuals come from sites dating to the LIP 
and are associated with the Antofagasta, Loa-San Pedro, Pica-Tarapacá cultures. In order to compare coast versus inland, we divided the Pica-Tarapacá sample into "Tarapacá Coast" (teeth $n=7$; bone $n=13$ ) and "Tarapacá Inland" (teeth $n=20$; bone $n=42$ ). The Loa-San Pedro (teeth $n=9$; bone $n=42$ ) and Antofagasta (teeth $n=1$; bone n=5) cultures were kept as independent groups. Previously published data for the sites of Pica 8 (Tarapacá Inland) and Quitor 6 (Loa San Pedro) are included for comparison (Santana-Sagredo et al., 2015). Chronological data for some of the sites analysed here is presented in Supplementary Information 1.

Samples were selected in order to compare different moments in the lives of individuals (Hillson, 1996). For tooth enamel and bone apatite $\delta^{13} \mathrm{C}$ and $\delta^{18} \mathrm{O}$ were analysed, while for bone collagen $\delta^{13} C_{\text {coll }}$ and $\delta^{15} \mathrm{~N}$ were studied. Samples were obtained from the Instituto de Investigaciones Arqueológicas y Museo RP Gustavo Le Paige (San Pedro de Atacama - SPA), Museo Regional de Iquique (Iquique), Museo de Antofagasta (Antofagasta), Museo Nacional de Historia Natural (Santiago) and Departamento de Antropología-Universidad de Chile (Santiago).

Difficulties with sampling should be noted as they affected the distribution of samples across sites. Firstly, there are few samples from the Instituto de Investigaciones Arqueológicas (SPA), since most of the human collections in this museum are skulls collected by the Belgian priest Gustavo Le Paige during the 1940s-1960s. It was not possible to samples complete crania due to conservation regulations at the institutions. However, it was possible to identify some skull fragments broken post-mortem, which were collected for analysis. A similar situation occurred in the Natural History Museum of Santiago.

Mainly adults were considered in the analysis. Sex and age information followed catalogue entries in the museum and university collections, and was estimated when 
not available by one of us (FSS) according to standard osteological criteria (Buikstra and Ubelaker, 1994). However, two children (6-8 years) and two juveniles (15 years) were included in the sample, all from the Pica 8 cemetery.

\subsection{Methods}

Bone collagen was extracted using a modified version of the Longin method (1971). In-house standards alanine $\left(\delta^{13} \mathrm{C}=-26.9 \% ; \delta^{15} \mathrm{~N}=-1.63 \%\right)$, bovine liver $\left(\delta^{13} \mathrm{C}=-24.4 \%\right.$; $\delta^{15} \mathrm{~N}=7.76 \%$ ) , and seal collagen $\left(\delta^{13} \mathrm{C}=-13.3 \% ; \delta^{15} \mathrm{~N}=17.3 \%\right.$ ) were used for calibrating the carbon and nitrogen isotope measurements. The international standard IAEA-CH6 $\left(\delta^{13} \mathrm{C}=-10.4 \%\right.$ ) standard was also included for the calibration of carbon isotope values, given the possibility of high $\mathrm{C}_{4}$ consumption in northern Chilean populations. Samples were analysed in duplicate in a SER-CON 20/22 continuous flow isotope ratio mass spectrometer coupled with an elemental analyser at the Research Laboratory for Archaeology and the History of Art of the University of Oxford. Precision is calculated as $\pm 0.1 \%$ o for $\delta^{13} \mathrm{C}$ and $\pm 0.3 \%$ o for $\delta^{15} \mathrm{~N}$, based on multiple measurements of the standards.

Bone apatite was pre-treated following Smith's protocol (2005) for unfossilized/recent bone, as she showed that prolonged immersion in $\mathrm{NaOCl}$ followed by an acetic acid wash shifts the isotope values (cf. Pellegrini and Snoeck 2016). Here, bone samples were left in acetic acid $(0.1 \mathrm{M})$ only for five minutes. Measurement of carbon and oxygen isotopes was carried out in duplicate in a Finnigan MAT 252 mass spectrometer coupled to a Gas bench II, in the Stable Light Isotope Laboratory of the University of Cape Town. International standards NBS 18 and NBS 19 together with internal marble standards were used for calibrating the results. The precision for carbon and oxygen isotope measurements was estimated as $0.15 \%$. 
Enamel apatite was pre-treated following Sponheimer (1999). This protocol is similar to that for bone apatite, but the samples were left for 10 rather than five minutes in $0.1 \mathrm{M}$ acetic acid. Samples were analysed in the Stable Light Isotope Laboratory of the University of Bradford. Carbon and oxygen isotopes were measured in a Thermo Finnigan Delta V Advantage mass spectrometer coupled to a Gasbench II. The international standards $\mathrm{CO}-1$ and $\mathrm{CO}-8$ together with Merck $\mathrm{CaCO}_{3}$ were used to calibrate the results. Precision for the carbon and oxygen isotopes results was $0.1 \%$.

Shapiro-Wilk tests showed that most of the stable isotope data did not show normal distributions. For this reason, non-parametrical tests were applied for comparing groups. Mann-Whitney $U$-tests were used when comparing two groups. Kruskal Wallis tests with post hoc Dunn Test and a Bonferroni correction were performed when comparing more than two groups. All the statistical analyses were run in $R$ ( $R$ Project for Statistical Computing 2003).

\section{Results}

\subsection{Bone Collagen}

Most of the samples analysed show good collagen preservation. However, four from Loa-San Pedro group, one from Tarapacá Coast and two from Tarapacá Inland did not present acceptable atomic weight $\mathrm{C} / \mathrm{N}$ ratios (Table 1) and were excluded (DeNiro, 1985). In addition, two individuals from Tarapacá Coast and five from Loa-San Pedro did not yield collagen. For Tarapacá Inland, C/N ratios up to 3.7 were retained in the analysis since they are likely caused by the presence of lipids rather than bad collagen preservation (Santana-Sagredo et al. 2015; 2017). Despite this, their isotope values do not differ from those individuals with $\mathrm{C} / \mathrm{N}$ ratios between 2.9-3.6.

Descriptive statistics for all the groups are presented in Table 2. More detailed information on the descriptive statistics for each of the sites analysed here can be 
found in table 1 of Supplementary Information. Both $\delta^{13} \mathrm{C}_{\text {coll }}$ and $\delta^{15} \mathrm{~N}$ values are very high for all the individuals in the Antofagasta group (Fig. 2a), with means of $11.7 \pm 0.4 \%$ and $25.5 \pm 0.6 \%$, respectively. Sex-based differences could not be assessed due to the presence of only one female in the sample. In contrast to Antofagasta, LoaSan Pedro shows lower $\delta^{13} \mathrm{C}_{\text {coll }}$ and $\delta^{15} \mathrm{~N}$ values (Fig. $2 \mathrm{a}$ ) with means of $-14.3 \pm 1.2 \%$ o and $11.5 \pm 1.5 \%$. Mann-Whitney $U$-tests for both $\delta^{13} \mathrm{C}_{\text {coll }}(Z=0.522, p=0.612)$ and $\delta^{15} \mathrm{~N}$ $(Z=-0.843, p=0.409)$ show no significant differences between females and males.

The Tarapacá Coast group is similar in isotopic composition to Antofagasta (Fig. 2a), with high means of $-11.5 \pm 1.3 \%$ and $25.5 \pm 1.6 \%$ for $\delta^{13} \mathrm{C}_{\text {coll }}$ and $\delta^{15} \mathrm{~N}$, respectively. No comparisons by sex could be carried out due to the apparent absence of female individuals, though it was not possible to estimate the sex of seven individuals. Tarapacá Inland shows means of $-11.0 \pm 2.5 \%$ and $17.7 \pm 4.2 \%$ for $\delta^{13} \mathrm{C}_{\text {coll }}$ and $\delta^{15} \mathrm{~N}$, respectively. Intra-group comparison presents no significant differences between females and males in $\delta^{13} C_{\text {coll }}(Z=-0.57 ; p=0.58)$ or $\delta^{15} \mathrm{~N}(Z=1.75 ; p=0.08)$.

Intergroup comparisons show significant differences for $\delta^{13} \mathrm{C}_{\text {coll }}$ between the Loa-San Pedro versus Tarapacá Coast (Kruskal-Wallis $\chi^{2}=39.58, p<0.05$; post hoc Dunn test $Z=-3.046 ; p=0.000$ ), and Tarapacá Inland (Kruskal-Wallis $\chi^{2}=39.58, p<0.05$; post hoc Dunn test $Z=-6.216 ; p=0.000)$. When comparing $\delta^{15} \mathrm{~N}$ values among the four groups, significant differences are observed for all (Kruskal- Wallis $\left.\chi^{2}=72.48 ; p<0.05\right)$ with the exception of Tarapacá Coast versus Antofagasta.

\subsection{Enamel apatite}

Results for enamel apatite are presented in Tables 1 and 2 and Fig. 3a. Only one Antofagasta sample was analysed, with $-9.2 \%$ for $\delta^{13} C_{e n}$ and $-5.8 \%$ for $\delta^{18} \mathrm{O}_{\text {en }}$. The $\delta^{18} \mathrm{O}_{\mathrm{en}}$ value is lower compared to those observed for bone apatite $\delta^{18} \mathrm{O}_{\mathrm{bn}}$ (Fig. 3a, b), which show values closer to $-1.5 \%$. Loa-San Pedro provides means of $-7.1 \pm 2.3 \%$ for 
$\delta^{13} \mathrm{C}_{\text {en }}$ and $-6.2 \pm 1.1 \%$. No significant differences are seen between females and males for $\delta^{13} C_{e n}(Z=0.42, p=0.74)$ or $\delta^{18} O_{e n}(Z=0.00, p=1.00)$.

Tarapacá Coast shows averages for $\delta^{13} \mathrm{C}_{\mathrm{en}}$ and $\delta^{18} \mathrm{O}_{\mathrm{bn}}$ of $-7.2 \pm 3.0 \%$ and $-7.7 \pm 1.1 \%$, respectively. No intra-group comparisons are possible due to the absence of identified females. Tarapacá Inland is comparatively ${ }^{13} \mathrm{C}$-enriched, a2veraging $-5.0 \pm 3.5 \%$. The mean for $\delta^{18} \mathrm{O}_{\mathrm{bn}}$ is $-8.6 \pm 1.7 \%$. Intra-group comparisons for enamel apatite indicate no significant differences by sex for $\delta^{13} C_{e n}(Z=-0.29, p=0.79)$ or $\delta^{18} O_{b n}(Z=0.99, p=0.34)$.

Inter-group comparisons do not suggest significant differences among the groups for $\delta^{13} C_{e n}$ values (Kruskal-Wallis $\chi^{2}=5.21, p>0.05$ ). Significant differences for $\delta^{18} O_{b n}$ were only observed for the Loa-San Pedro versus Tarapacá Inland groups (Kruskal-Wallis $\chi^{2}=16.36, p<0.05 ;$ post hoc Dunn Test $Z=3.42, p=0.001$ ).

\subsection{Bone apatite}

Results for $\delta^{13} \mathrm{C}_{\mathrm{bn}}$ and $\delta^{18} \mathrm{O}_{\mathrm{bn}}$ are presented in Tables 1 and 2 and Fig. $2 \mathrm{~b}$ and $3 \mathrm{~b}$. The Antofagasta means are $-8.0 \pm 0.8 \%$ and $-1.4 \pm 0.8 \%$ for $\delta^{13} \mathrm{C}_{\mathrm{bn}}$ and $\delta^{18} \mathrm{O}_{\mathrm{bn}}$, respectively. Sex-based comparisons could not be carried out due the presence of only one female in the sample. The Loa-San Pedro groups average $-8.9 \pm 1.1 \%$ for $\delta^{13} C_{b n}$ and $-3.9 \pm 0.9 \%$ for $\delta^{18} \mathrm{O}_{\mathrm{bn}}$. Again there are no significant differences between females and males for $\delta^{13} C_{b n}(Z=0.20, p=0.85)$ and $\delta^{18} O_{b n}(Z=0.94, p=0.35)$.

The Tarapacá Coast groups show means of $-9.6 \pm 1.3 \%$ for $\delta^{13} C_{b n}$ and $-5.3 \pm 1.8 \%$ for $\delta^{18} \mathrm{O}_{\mathrm{bn}}$. No intra-group comparisons were made due to the absence of females.

Tarapacá Inland groups show a mean of $-6.0 \pm 2.6 \%$ for $\delta^{13} C_{b n}$ and $-7.6 \pm 1.4 \%$ for $\delta^{18} \mathrm{O}_{\mathrm{bn}}$. As with the previous groups no significant differences between females and males were found for $\delta^{13} C_{b n}$ (Mann Whitney $U$ test $Z=-1.24, p=0.21$ ) and $\delta^{18} \mathrm{O}_{b n}($ Mann Whitney $U$ test $Z=0.40, p=0.70)$. Inter-group comparisons for bone apatite $\delta^{13} C_{b n}$ show significant differences between Tarapacá Inland versus Loa-San Pedro (Kruskal-Wallis 
$\chi^{2}=28.33, p<0.05$; post hoc Dunn test $Z=-4.43, p=0.000$ ) and Tarapacá Coast (Kruskal-Wallis $\chi^{2}=28.33, p<0.05$; post hoc Dunn Test $Z=-4.14, p=0.001$ ). On the other hand, most of the groups have significant differences regarding their $\delta^{18} \mathrm{O}_{\mathrm{bn}}$ values (Kruskal-Wallis $\chi^{2}=69.03, p<0.05$ ) except for Loa-San Pedro versus Tarapacá Coast and Antofagasta.

\section{Dietary composition during the LIP}

Results obtained for $\delta^{13} \mathrm{C}_{\text {coll }}, \delta^{13} \mathrm{C}_{\mathrm{bn}}$ and $\delta^{15} \mathrm{~N}$ suggest there is clear isotopic patterning associated with location and cultural affiliation, as was previously observed for the Pica 8 and Quitor 6 cemeteries (Santana-Sagredo et al., 2015). The Antofagasta and Tarapacá Coast groups have high $\delta^{13} \mathrm{C}$ and $\delta^{15} \mathrm{~N}$ values, indicating marine-focussed diets. The Tarapacá Inland group presents great diversity in $\delta^{13} \mathrm{C}$ and $\delta^{15} \mathrm{~N}$. In contrast, the Loa-San Pedro people had a very consistent and homogenous diet composition compared to Tarapacá. Therefore, the four groups can be identified clearly by their cultural association, geographical location and diet.

To investigate these patterns further, human results were plotted together with published archaeological and modern flora and fauna values for the area (Fig. 4). Clearly Antofagasta and Tarapacá Coast fall closer to the marine resources and $\mathrm{C}_{3}$ plants. However, $\delta^{13} \mathrm{C}$ results for bone collagen and apatite suggest there was also maize ingestion by some coastal individuals, though this does not reach the levels seen in at Tarapacá Inland. Tarapacá Inland plots closer to the values expected for consumption of $\mathrm{C}_{4}$ crops, compared to the coastal groups and Loa-San Pedro. At the same time, it falls in between terrestrial and marine resources, strongly suggesting a mixed diet. It is of great relevance to consider the possible impact of the $\delta^{15} \mathrm{~N}$ crop values on human diet (Santana-Sagredo et al., 2017). It has been reported that fertilisers such as llama dung and seabird guano can cause considerable enrichment in 
${ }^{15} \mathrm{~N}$ (Szpak et al., 2012). The Loa-San Pedro group, on the other hand, plots closer to terrestrial $\mathrm{C}_{3}$ resources (wild fruits and crops) and camelids.

The dietary information provided by the isotopic analysis is in strong agreement with the archaeological evidence. As discussed above, sites along the Pacific Coast of northern Chile have yielded mainly marine resources, including fish, mussels, octopus, marine birds and sea mammals (Núñez, 1984; Moragas, 1995; Uribe, 2006; Ballester and Clarot, 2014). This evidence supports the continuity of a strong maritime tradition from very early times until the LIP and later periods. This has also been observed isotopically for other coastal populations in northern Chile (Santana et al., 2012; Roberts et al., 2013; Pestle et al., 2015). Judging by their carbon bone and enamel apatite values of ca. $-9 \%$, it is suggested that maize was not a fundamental component of coastal population diets, although it clearly did feature to some extent, as indicated by its presence at some coastal sites (Uribe, 2006). This could account for the significant differences for $\delta^{13} \mathrm{C}_{\mathrm{bn}}$ observed between the Tarapacá Coast and Inland groups. Statistically significant differences in $\delta^{15} \mathrm{~N}$ were also reported for these two groups. Tarapacá Inland shows high variability in $\delta^{15} \mathrm{~N}$, ranging from $10 \%$ to $24 \%$. This situation was observed for Quillagua in northern Chile, another Tarapacá Inland site (Santana-Sagredo et al., 2016). Many individuals were probably consuming a rather mixed terrestrial-marine diet resulting in $\delta^{15} \mathrm{~N}$ values close to $15 \%$. The coastal influence in Tarapacá Inland is clear, following the considerable marine evidence found at sites such as Tarapacá-40, Pica 8 and Quillagua's Cementerio Oriente, located up to $90 \mathrm{~km}$ from the coast (Núñez, 1984; Uribe, 2006; Santana-Sagredo et al., 2016). In addition, it is clear that Tarapacá Inland had by far the highest maize consumption of all the groups analysed here, while also having access to marine resources. 
Loa-San Pedro differs significantly from Antofagasta and Tarapacá Coast and Inland, exhibiting the lowest ${ }^{13} \mathrm{C}_{\text {coll }}$ and $\delta^{15} \mathrm{~N}$ values. Maize did not dominate the diet, which instead exhibits a mixed $\mathrm{C}_{3}-\mathrm{C}_{4}$ diet, similar to results previously obtained for the LIP in the region (Santana-Sagredo et al., 2015; Pestle et al., 2016). This pattern seems to extend back to the preceding Middle Period in the Loa San Pedro (Núñez, 1995; Pestle et al., 2016, Uribe et al., 2016). The application of Bayesian models for reconstructing diet in San Pedro during the Middle Horizon suggests an increased input of legumes (Pestle et al., 2016).

Tooth enamel isotope data show a general tendency to be more enriched in ${ }^{13} \mathrm{C}$ compared to bone apatite. This could be related to a different type of diet consumed during childhood that was rich in $\mathrm{C}_{4}$ resources. However, physiology factors as well as carbonate pre-treatment could be playing a role in these differences. Pre-treatment effects on bone apatite cannot be ruled out due to the greater susceptibility of bone mineral to alteration (Pellegrini and Snoeck, 2016).

\section{Water sources and oxygen isotopes}

Regarding $\delta^{18} \mathrm{O}$ in tooth enamel and bone, results show variability in the values by cultural group, as well as significant differences between them, which is to be expected bearing in mind the complex hydrology characterising the Atacama Desert (Magaritz et al. 1990; Aravena, 1995). Still, each group shows values falling within the local ranges, with only a few exceptions, supporting the strong local traditions observed in the 'dietary' isotopic results.

The Antofagasta individuals show the most ${ }^{18} \mathrm{O}$-enriched composition for both bone and enamel apatite in this study. As they are located next to the coast, it is probable they had access to springs with enriched ${ }^{18} \mathrm{O}$. In fact, water $\delta^{18} \mathrm{O}_{\text {SMOw }}$ values from three 
different springs in the coast of Antofagasta range between $-2.2 \%$ and $-0.9 \%$ (Herrera and Custodio, 2014). Converting the Antofagasta human $\delta^{18} \mathrm{O}$ values from carbonate VPDB to drinking water values (SMOW), we obtain a value of $-9.5 \%$ for $\delta^{18} \mathrm{O}_{\text {en }}$ and an average of $-1.5 \pm 1.4 \%$ for $\delta^{18} \mathrm{O}_{\mathrm{bn}}$ using equation 1 in Chenery et al. (2012), and a value of $-9.0 \%$ for $\delta^{18} \mathrm{O}_{\text {en }}$ and a mean of $-1.8 \pm 1.3 \%$ for $\delta^{18} \mathrm{O}_{\mathrm{bn}}$ using their equation 2 . Values for $\delta^{18} \mathrm{O}$ in bone apatite fall inside the range observed for the Antofagasta springs. However the enamel $\delta^{18} \mathrm{O}$ values suggest a different water source probably from a different spring more depleted in ${ }^{18} \mathrm{O}$ considering there are no rivers close to Antofagasta. Nevertheless, cultural practices can also modify water, through cooking and alcohol fermentation (Knudson et al., 2009). Therefore, these aspects also need to be considered as factors influencing the $\delta^{18} \mathrm{O}_{\text {en }}$ values.

Most of the Loa-San Pedro $\delta^{18} \mathrm{O}$ values fall in the range expected for humans in this region (Knudson, 2009; Knudson and Torres-Rouff, 2009; Knudson and Torres-Rouff, 2015). These previous results show that the human $\delta^{18} \mathrm{O}_{\mathrm{VPDB}}$ values in the region range from approximately $-7 \%$ to $-0 \%$. The high variability for the Loa-San Pedro is not surprising because during a single year the $\delta^{18} \mathrm{O}$ values from the San Pedro and Vilama rivers, located in the Atacama Oases, can vary by about 4\%o (Aravena, 2013 pers. comm). The high evaporation rates occurring in the Atacama together with the complex groundwater system coming from the Andes lead to great variability of the oxygen isotope composition in meteoric waters (Magaritz et al., 1990; Aravena, 1995). Three measured $\delta^{18} \mathrm{O}_{\text {Smow }}$ values for the San Pedro River average $-7.5 \pm 0.6 \%$ o (Knudson and Torres-Rouff 2015). In addition, the Loa River shows values of $-11.2 \%$ to $-6.2 \%$ in different parts of its course. For the Caspana area (Upper Loa) the $\delta^{18} \mathrm{O}$ values are around $-7.5 \%$ and $-6.3 \%$, while for Toconce the value is close to $-9 \%$ o (Aravena and Suzuki, 1990; Knudson and Torres-Rouff. 2015). When converting tooth enamel $\delta^{18} \mathrm{O}_{\text {VPDB }}$ values to $\delta^{18} \mathrm{O}_{\text {SMOW }}$ drinking water values in the Loa-San Pedro groups 
we observed means of $-10.3 \pm 2.0 \%$ using equation 1 in Chenery et al. (2012) and $9.7 \pm 1.8 \%$ using equation 2 . For bone apatite the converted $\delta^{18} \mathrm{O}$ values using equations 1 and 2 show means of $-6.1 \pm 1.6 \%$ and $-5.9 \pm 1.4 \%$, respectively. The differences observed between the measured values in modern rivers and the archaeological drinking water $\delta^{18} \mathrm{O}$ values could be explained by the high variation in meteoric waters. However, Pollard et al. (2011) report an error of at least $3 \%$ for these conversion equations.

Tarapacá Coast and Inland groups both have lower $\delta^{18} \mathrm{O}$ values compared to Atacama and Antofagasta. The groundwater systems of Pampa del Tamarugal carry water directly from the mountains, only rising to surface to form springs and oases, and so reducing ${ }^{18} \mathrm{O}$ enrichment through evaporation and leading to low $\delta^{18} \mathrm{O}$ values (Magaritz et al., 1990; Aravena, 1995). The oxygen isotope results obtained for tooth enamel and bone apatite for Tarapacá inland follows this pattern of depleted ${ }^{18} \mathrm{O}$. This has been reported before for human bone apatite of the Pica 8 cemetery with most values ranging between $-6 \%$ o to $-9 \%$ (Santana-Sagredo et al., 2015). However, at least five individuals show values outside this range, suggesting non-local origins.

A similar situation occurs on the Tarapacá coast. This is not surprising because the groundwater system reaches the coast forming small springs, though there are no published values on the water composition of these springs.

Values of $\delta^{18} \mathrm{O}_{\text {SMOw }}$ in spring waters from the oasis at Pica, part of the Tarapacá Inland group, range from $-13.1 \%$ o to $-10.9 \%$ (Magaritz et al., 1990; Aravena, 1995). The tooth enamel $\delta^{18} \mathrm{O}$ values for converted to drinking water with equation 1 one show a mean of $-14.7 \pm 3.1$ while with equation 2 the mean is $-13.6 \pm 2.8 \%$ (Chenery et al., 2012 ). On the other hand, for bone apatite the conversions show averages of $-12.7 \pm 2.5 \%$ and $12.0 \pm 2.2 \%$ for when using equations 1 and 2 , respectively. For both tissues the values fall close to those observed in the spring waters. 
Enamel and bone apatite present, as with carbon isotopes, differences for some of the cultural groups analysed here. While bone apatite is more enriched in ${ }^{18} \mathrm{O}$, most of the values for both tissues are still in the 'local' range expected for each area, though only because these tend to be highly variable themselves. As no first molars were analysed here, complications arising from nursing effects are not a factor. Further research is needed in order to better understand the variability of oxygen isotopes in the Atacama Desert.

\section{Non-Locals, mobility and changing diets}

The previous sections discussed the main patterns for dietary and drinking water source characteristics of the Antofagasta, Loa-San Pedro and Tarapacá (Coast and Inland) cultural groups. However, in three of these groups non-local individuals were identified (Fig. 5).

Loa-San Pedro burial T54 from Quitor 6 exhibits a particularly high enamel $\delta^{13} \mathrm{C}$ ratio of $-2.1 \%$, that must indicate high reliance on a $\mathrm{C}_{4}$ crop, i.e., maize. This female is the only individual in the entire Loa-San Pedro group analysed here such a high degree of maize consumption. She also presents the lowest $\delta^{18} \mathrm{O}_{\text {en }}$ value $(-8.1 \%)$ for the Loa-San Pedro group, suggesting a non-local water-drinking source during childhood. Nevertheless, she was buried with local Atacama pottery (Costa-Junqueira, 1988). Yet, only this and one other individual at Quitor 6 were interred with hooks made of wood for attaching transport bags on camelids, suggesting involvement in caravan activities.

For the Tarapacá Coast group, individual PIS5-34 from Pisagua 5 presents a drastic change in its dietary patterns from childhood to adulthood (Fig. 5). The second premolar $\delta^{13} \mathrm{C}$ is $-3 \%$, while for bone apatite the value drops dramatically to $-11 \%$. The 
tooth enamel $\delta^{13} \mathrm{C}$ value is particularly high compared to the other coastal individuals (Table 1), suggesting a heavy reliance on maize, resembling those observed for the Pica 8 cemetery in Tarapacá Inland. In fact, its $\delta^{18} \mathrm{O}_{\text {en }}$ value is also very similar to those from Pica. However, oxygen isotopes for the coast of Pisagua (when compared to the other coastal individuals) are also very similar to the values in Pica.

Pica 8 individuals from the Tarapacá Inland group show great diversity, with some consuming predominantly terrestrial- $\mathrm{C}_{3}$ diets, while others were consuming marine diets with no $\mathrm{C}_{4}$ resources (Fig. 5). The first group is formed by individuals B0420, B0427 and B0453 (Santana-Sagredo et al., 2015) defined by their terrestrial- $\mathrm{C}_{3}$ diet. Individuals B0420 (female) and B0427 (male) show low $\delta^{13} \mathrm{C}_{\text {coll }}, \delta^{15} \mathrm{~N}$ and $\delta^{18} \mathrm{O}$ consistent with a predominantly $\mathrm{C}_{3}$ terrestrial diet and with possible origins in the altiplano, with no substantial isotopically detectable changes in diet between infancy and last years of life. The female had burial offerings that include local Pica-Tarapacá pottery and textiles, while the male mainly had neither pottery nor textile, but instead objects associated with either hunting or conflict (Zlatar, 1984).

Individual B0453 (female) followed a similar pattern to that of B0420 and B0427 in childhood. However, the difference between them is that individual B0453 changed her diet during her last years of life with a marked increase in bone collagen carbon and nitrogen isotope values. This suggests the consumption of $\mathrm{C}_{4}$ resources and marine foods. No information is available on her burial offerings.

The second group is formed by individuals B0424 (male) (Santana-Sagredo et al. 2015) and B0478 (female). Neither show significant isotopic/dietary changes during life, with an isotope composition suggesting a marine diet with no clear $\mathrm{C}_{4}$ influence. 
Moreover, their $\delta^{18} \mathrm{O}$ values are consistent with a coastal origin. There is no information on their funerary offerings.

\section{Mobility during the LIP: Colonies, caravans or other social relationships?}

The results obtained for the different cultural groups here clearly show local dietary patterns as well as local drinking water sources. It is known from the archaeological evidence that altiplano communities based their diets on terrestrial resources (Schiappacasse et al., 1989), predominately the consumption of potatoes and quinoa as well as camelids (including dry meat) and small mammals (Núñez, 1984; Murra, 1975; Schiappacasse et al., 1989). At such high altitudes maize agriculture is quite difficult, hence the consumption of altiplano crops such as tubers and $\mathrm{C}_{3}$ grains. No isotopic evidence for a typical altiplano diet was observed in any of the cultural groups analysed here, with the exception of the non-locals. In this sense, the Murra hypothesis (1972) of altiplano colonies in the lowlands including valleys and coast for the LIP in northern Chile (Schiappacasse et al., 1989), can be rejected from an isotopic/dietary perspective. In addition, the material culture evidence for these groups also strongly suggests local traditions. For instance, the Pica-Tarapacá pottery and textiles styles prevail in the interior and on the coast (Uribe, 2006). A similar situation is observed for the Loa-San Pedro culture (Uribe, 2012). Thus, exotic objects as well as non-local diets are then understood as particular cases, outliers inside these regional traditions.

The Loa-San Pedro culture is characterised as having closer contacts with the altiplano (Uribe, 2012). However, these contacts did not affect their food traditions, comprising a mixed $\mathrm{C}_{3}-\mathrm{C}_{4}$ diet including terrestrial fauna. $A$ similar situation is observed for the coast of Antofagasta and Tarapacá in that a strong maritime subsistence orientation persisted through time. Inland Tarapacá is not an exception showing clear connections between the coast and valleys, with a mixed terrestrial-marine diet, including maize consumption. 
The presence of individuals with different dietary and mobility histories is clear in the Loa-San Pedro and Tarapacá Inland groups. But the question is who were they? And why did they have different diets and places of origin? The gyratory mobility theory proposes that small groups of people travelled in caravans through different locations in order to exchange objects and goods. These highly specialised pastoralist groups probably came from the altiplano, as suggested by Núñez and Dillehay (1995). In this sense, we would expect to see a pattern in terms of their isotope composition with low values for their $\delta^{13} \mathrm{C}, \delta^{15} \mathrm{~N}$ and $\delta^{18} \mathrm{O}$, reflecting a terrestrial- $\mathrm{C}_{3}$ highland diet.

A few non-local individuals were identified here as coming from the altiplano. However, no patterns were observed for them that would suggest a single origin. We also find some non-locals that did not change their diets at all during their last years of lives, while others had drastic fluctuations. In addition, one of them was buried with local funerary offerings.

More remarkable is the fact that no differences were observed by sex in any of the sites. Clearly, gender was not playing a major role in terms of dietary patterns or mobility. This contrasts with the modern ethnographic information for caravans in the Andes, in which only men are moving (Nielsen, 2009; Pimentel, 2012; Torres-Rouff et al., 2012). This has also been the basis for describing the caravan model. Both sexes, appear to have had access to all type of resources, and both women and men were moving around the Atacama Desert. The presence of non-local men and women in these sites also calls for a consideration of the possible move individuals of both sexes from one group to the other in order to create new kin relationships (i.e., through marriage) (Martínez, 1998) and possibly territorial regulations as well as political alliances, allowing access to local areas for the foreign travellers. 
Torres-Rouff et al (2012) also discuss gender and age, including females and children, when studying mobility in the Atacama Desert based on individuals $(n=10)$ that died travelling and were buried next to the roads, dating from the Formative to Late Periods. They relate part of the burials found in the interior to individuals associated with llama caravans (Núñez and Dillehay, 1995). They consider as well an expanded vision on the coastal mobility proposed by Pimentel (2012), relating the movements of these individuals not only to logistic and caravan activity but also to residential mobility. The aim of this residential mobility would have been to collect wild fruits as algarrobo in sites close to the coast (Torres-Rouff et al., 2012), again associating human movements with economical aspects. However, we believe people moved for different reasons that go beyond exchange, trade or economy-related aspects. As mentioned before, kinship relationships or political alliances could be playing an important role in the mobility patterns and dynamics during the LIP.

The results obtained here also suggest people changed their diets and moved at different times in their lives, during childhood, from childhood to adulthood or only during their last years of life. No consistent patterns are observed in this regard. This evidence suggests mobility patterns were variable, independent from each other, and that occurred at different moments in the life of a person. Based on these results, new question rises on how and why these people moved.

It is proposed here that mobility patterns were different, and not only related to small caravan groups crossing the desert in order to exchange goods, or the imposition of altiplano colonies. Comparing the archaeological and isotopic evidence becomes a necessary step in order to better understand mobility in context.

\section{Conclusions}

Isotopic analyses were carried out on human bone and tooth from the Antofagasta, Loa-San Pedro and Tarapacá cultural groups. They each showed local dietary 
patterns, which are in general agreement with the archaeological evidence. Local diet traditions prevail for northern Chile during the LIP, together with their material culture such as textiles and pottery types. However, non-local diets and important isotopic/diet changes were detected in three of the cultural groups. These individuals indicate a different system of mobility in the Atacama Desert, in which some adapted and moved to the local diet traditions, while other retained the diets of their origin communities. This situation included men and women and it happened during different moments of the individual's lives. Mobility was probably associated with kinship relationships and the creation of political alliances. Our results caution about a different situation that cannot be explained following the classic mobility models, based exclusively on economical reasons. Further research is needed in order to understand the diet changes and mobility patterns during the LIP in the South Central Andes, using better oxygen baselines for the water sources and radiogenic strontium isotope analyses.

\section{Acknowledgments}

We would like to thank all the museums and institutions that permitted sampling for this study. We thank Becas Chile-CONICYT Programa de estudios de Doctorado en el extranjero for funding this research as well as the first author (FSS) PhD studies at the University of Oxford.

We are thankful to Rodrigo Loyola and Sebastián Santana Sagredo for their help with the map, and to Alejandro Clarot and Lorena Becerra for helping with the sampling. We also thank to the $\mathrm{FPCl}$ and Anillo Projects. Finally, we thank the Editor in Chief of Quaternary International Min-Te Chen and the Associate Editor Florent Rivals for their help during the process of publishing this special issue.

\section{References}


1. Ambrose, S.H. 1991. Effects of diet, climate and physiology on nitrogen isotope abundances in terrestrial foodwebs. J Archeol Sci 18, 293-317

2. Ambrose, S.H., Norr, L. 1993. Experimental evidence for the relationship of the carbon isotope ratios of whole diet and dietary protein to those of bone collagen and carbonate. In: Lambert JB, Grupe G. (Eds.), Prehistoric Human Bone: Archaeology at the Molecular Level. Springer-Verlag, Berlin, pp. 1-37.

3. Andrade, P., Fernandes, R., Codjambassis, K., Urrea, J., Olguín, L., Rebolledo, S., Lira, F., Aravena, C., Berríos, M. 2015. Subsistence continuity linked to consumption of marine protein in the formative period in the interfluvic coast of northern Chile: re-assesing contacts with agropastoral groups from highlands. Radiocarbon 57, 679-688.

4. Aravena, R., Suzuki, O. 1990. Isotopic evolution of river water in the northern Chile region. Water Resour Res 26, 2887-2895.

5. Aravena, R. 1995. Isotope hydrology and geochemistry of northern Chile groundwaters. Bull Inst fr étud andin 24, 495-503.

6. Ballester, B., Clarot, A. 2014. La gente de los túmulos de tierra, estudio, conservación y difusión de colecciones arqueológicas de la comuna de Mejillones. Gráfica Marmor, Santiago.

7. Berenguer, J. 2004. Caravanas interacción y cambio en el Desierto de Atacama (PhD Dissertation). University of Illinois.

8. Bittman, B. 1984. Interrelaciones étnicas establecidas a lo largo de la costa norte de Chile y sur del Perú en el contexto de la colonia: Los camanchacas. Estud Atacameños 7, 443-454.

9. Buikstra, J., Ubelaker D. 1994. Standards for data collection from human skeletal remains. Archaeological Survey Research Series 44. Fayetteville, Arkansas.

10. Camus, P. 2001. Biogeografía marina de Chile continental. Rev Chil Hist Nat 74, 587-617.

11. Chenery, C.A., Pashley, V., Lamb, A., Sloane, H.J., Evans, J.A. 2012. The oxygen isotope relationship between the phosphate and structural carbonate fractions of human bioapatite. Rapid Comm in Mass Spectrom 26, 309-319.

12. Costa-Junqueira MA. 1988. Reconstitución física y cultural de la población tardía del cementerio de Quitor-6 (San Pedro de Atacama). Estud Atacam 9, 99-126.

13. Dansgaard W. 1964. Stable isotopes in precipitation. Tellus A 16, 436-68. 
14. DeNiro, M. 1985. Postmortem preservation and alteration of in vivo bone collagen isotope ratios in relation to palaeodietary reconstruction. Nature 317, 806-809.

15. Díaz, F., Frugone, M., Gutiérrez, R., Latorre, C. 2016. Nitrogen cycling in an extreme hyperarid environment inferred from $\delta^{15} \mathrm{~N}$ analyses of plants, soils, and herbivore diet. Sci Rep. DOI: 10.1038/srep22226

16. Farquhar, GD., Ehleringer, J.R., Hubick. K.T. 1989. Carbon isotope discrimination and photosynthesis. Ann Rev Plant Phsyiol Mol Biol 40, 503-537.

17. Gutiérrez, J., López-Cortes, F., Marquet, P. 1998. Vegetation in an altitudinal gradient along the Río Loa in the Atacama Desert of northern Chile. J Arid Environ 40: 383-399.

18. Heaton, T. 1987. The ${ }^{15} \mathrm{~N} /{ }^{14} \mathrm{~N}$ ratios of plants in South Africa and Namibia: Relationship to climate and coastal/saline environments. Oecologia 74, 236246.

19. Hillson, S. 1996. Dental Anthropology. Cambridge University Press, Cambridge

20. Knudson, K., Torres-Rouff, C. 2009. Investigating cultural heterogeneity in San Pedro de Atacama, Northern Chile, through biogeochemestry and bioarchaeology. Am J Phys Anthropol 138, 473-485.

21. Knduson K, Torres-Rouff C. 2015. Investigating human responses to political and environmental change through paleodiet and paleomobility. Am J Phys Anthropol 157, 179-201.

22. Latorre, C., Betancourt, J., Rylander, K., Quade, J., Matthei, O. 2003. A vegetation history from the arid prepuna of northern Chile $\left(22-23^{\circ} \mathrm{S}\right)$ over the last 13.500 years. Palaeogeogr, Palaeoclimatol, Palaeoecol 194, 223-246.

23. Latorre, C., Betancourt, J., Rech, J., Quade, J., Holmgren, C., Placzek, C., Maldonado, A., Vuille, M., Rylander, K. 2005. Late Quaternary history of the Atacama Desert. In: Smith, M., Hesse, P. (Eds). Archaeology and Environmental History of the Southern Deserts. National Museum of Australia Press, Australia.

24. Lee-Thorp, J., Sponheimer, M. 2003. Three case studies used to reassess the reliability of fossil bone and enamel isotope signals for palaeodietary studies. $J$ Anthropol Archaeol 22, 208-216

25. Longin, R. 1971. New method of collagen extraction for radiocarbon dating. Nature 230, 241-242.

26. López, P., Cartajena, I., Loyola, R., Núñez, L., Carrasco, C. 2017. The use of hunting and herding spaces: Stable isotope analysis of Late Archaic and Early 
Formative camelids in the Tulan transect (Puna de Atacama, Chile). Int $\mathrm{J}$ Osteoarchaeol 27: 1059-1069.

27. Magaritz, M., Aravena, R., Peña, H., Suzuki, O., Grilli, A. Water chemistry and isotope study of streams and springs in northern Chile. J Hydrol 108, 323-341.

28. Marquet, P., Bozinovic, F., Bradshaw, G., Cornelius, C., González, H., Gutierrez, J., Hajek, E., Lagos, J., Lopez-Cortes, F., Nuñez, L., Rosello, E., Santoro, C., Samaniego, H., Standen, V., Torres-Mura, J., Jaksic, M. 1998. Los ecosistemas del desierto de Atacama y área andina adyacente en el norte de Chile. Rev Chil Hist Nat 71, 593-617.

29. Marino B.D,McElroy, M.B. 1991. Isotopic compositon of atmospheric $\mathrm{CO}_{2}$ inferred from carbón in $\mathrm{C}_{4}$ plant cellulose. Nature 349, 127-131.

30. Martínez JL. 1998. Pueblos del chañar y el algarrobo. Los Atacamas en el siglo XVII. DIBAM, Santiago.

31. Moragas, C. 1995. Desarrollo de las Comunidades Prehispánicas del Litoral Iquique-desembocadura Río Loa. Hombre Desierto 9, 65-80.

32. Murra, J. 1972. El "control vertical" de un máximo de pisos ecológicos en la economía de las sociedades andinas. In: Murra, J. (Ed) Visita a la provincia de León de Huánuco en 1562, Iñigo Ortiz de Zúñiga. Universidad Emilio Valdizán, Huánuco, pp. 429-472.

33. Nielsen, A. 2009. Pastoralism and the non-pastoralism world in the late preColumbian history of the Southern Andes (1000-1535). Nomadic Peoples 13: 17-35.

34. Núñez, L. 1984. Tráfico de complementariedad de recursos entre las tierras altas y el Pacífico en el área Centro-Sur Andina (PhD Dissertation). University of Tokyo: Tokyo.

35. Núñez, L. 1995. Cultura y conflicto en los oasis de San Pedro de Atacama. Editorial Universitaria, Santiago.

36. Núñez, L., Dillehay, T. 1995 [1978]. Movilidad giratoria, armonía social y desarrollo en los Andes Meridionales: patrones de tráfico e interacción económica. Universidad del Norte, Antofagasta.

37. Pellegrini, M., Snoeck, C. 2016. Comparing bioapatite carbonate pre-treatments for isotopic measurements: Part 2 - Impact on carbon and oxygen isotope compositions. Chem Geol 420, 88-96.

38. Pestle, W.J., Torres-Rouff, C., Gallardo, F., Ballester, B., Clarot, A. 2015. Mobility and Exchange among Marine Hunter-Gatherer and Agropastoralist Communities in the Formative Period Atacama Desert. Curr Anthropol 56, 121133. 
39. Pestle, W.J., Torres-Rouff, C., Hubbe, M. 2016. Modeling diet in times of change: The case of Quitor, San Pedro de Atacama, Chile. J Archaeol Sci Rep, 82-93.

40. Pimentel G. 2012. Redes viales prehispánicas en el Desierto de Atacama: viajeros, movilidad e intercambio (PhD Dissertation). Universidad Católica del Norte-Universidad de Tarapacá, San Pedro de Atacama.

41. Pollard, A.M., Pellegrini, M., Lee-Thorp, J. 2011. Technical note: Some observations on the conversion of dental enamel $\delta^{18} \mathrm{O}_{p}$ values to $\delta^{18} \mathrm{O}_{w}$ to determine human mobility. Am J Phys Anthropol 145, 499-504.

42. R Core Team. 2013. R: A language and environment for statistical computing. R Foundation for Statistical Computing: Vienna, Austria. URL http://www.Rproject.org/

43. Roberts, A., Pate, D., Petruzzelli, B., Carter, C., Westaway, M.C., Santoro, C.M., Swift, J., Maddern, T., Jacobsen, G., Bertuch, F., Rothhammer, F. 2013., Retention of hunter-gatherer economies among maritime foragers from Caleta Vitor, northern Chile, during the late Holocene: evidence from stable carbon and nitrogen isotopic analysis of skeletal remains. J Archaeol Sci 40, 23602372.

44. Rostworowski, M. 1989. Costa Peruana Preshipánica. Instituto de Estudios Peruanos, Lima.

45. Sanhueza J. 1982. Avances en las investigaciones sobre la prehistoria de la costa- sur interfluvial de Iquique I región-Chile. Actas del IX Congreso Nacional de Arqueología. Museo Arqueológico de La Serena, La Serena, 43-59.

46. Santana, F., Herrera, M.J., Uribe, M. 2012. Acercamiento a la paleodieta en la costa y quebradas tarapaqueñas durante el período Formativo: Análisis de isótopos estables a partir de tres casos de estudio. Bol Soc Chil Arqueol 41-42, 109-126.

47. Santana-Sagredo, F., Lee-Thorp, J.A., Schulting, R.J., Uribe, M. 2015. Isotopic evidence for divergent diets and mobility patterns in the Atacama Desert during the Late Intermediate Period (AD 900-1450). Am J Phys Anthropol 156, 374387.

48. Santana-Sagredo, F., Hubbe, M., Uribe, M. 2016. Isotopic Evidence for Marine Consumption and Mobility in the Atacama Desert (Quillagua, Northern Chile). Int J Osteoarchaeol 26, 476-489.

49. Santana-Sagredo, F., Schulting, R., Lee-Thorp, J., Agüero, C., Uribe, M., Lemp, C. 2017. Paired radiocarbon dating on human samples and camelid fibers and 
textiles from northern Chile: The case o Pica 8 (Tarapacá). Radiocarbon 59, 1195-1213.

50. Schiappacasse, V., Castro, V., Niemeyer, H. 1989. Los Desarrollos Regionales en el Norte Grande. In: Hidalgo, J., Schiappacasse, V., Niemeyer, H., Aldunate, C., Solimano, I. (Eds), Culturas de Chile. Prehistoria. Andrés Bello, Santiago, pp. 181-220.

51. Schoeninger, M., DeNiro, M. 1984. Nitrogen and carbon isotopic composition of bone collagen from marine and terrestrial animals. Geochim Cosmochim Acta $48,625-639$

52. Smith, J. 2005. Climate change and agropastoral sustainability in the Shashe/Limpopo river basin from AD 900 (PhD Dissertation). Johannesburg. University of Witwatersrand.

53. Sponheimer M. 1999. Isotopic paleoecology of the Makapansgat limeworks fauna (PhD Dissertation). The State University of New Jersey.

54. Sponheimer, M., Robinson, T., Roeder, A., Hammer, J., Passey, B., West, A., Cerling, T., Dearing, D., Ehleringer, J. 2003. Nitrogen isotopes in mammalian herbivores: Hair $\delta^{15} \mathrm{~N}$ values from a controlled feeding study. Int $\mathrm{J}$ Osteoarchaeol 13, 80-87

55. Szpak, P., Millaire, J., White, C., Longstaffe, F. 2012. Influence of seabird guano and camelid dung fertilization on the nitrogen isotopic composition of field-grown maize (Zea mays). J Archaeol Sci 39, 3721-3740.

56. Tieszen L, Chapman M. 1992. Carbon and Nitrogen isotopic status of the major marine and terrestrial resources in the Atacama Desert of Northern Chile. In Proceedings of the First World Congress on Mummy Studies. Museo Arqueológico y Etnográfico de Tenerife, Tenerife, 409-426.

57. Torres-Rouff, C., Pimentel, G., Ugarte, M. 2012. ¿Quiénes viajaban? Investigando la muerte de viajeros prehispánicos en el Desierto de Atacama (ca. 800 AC-1536 DC). Estud Atacam 43, 167-186.

58. Troll C. 1958. Las culturas superiores andinas y el medio geográfico. Instituto de Geografía, Universidad de San Marcos, Lima.

59. Uribe, M., 2006. Acerca de complejidad, desigualdad social y el complejo cultural Pica-Tarapacá en los Andes Centro-Sur (1000-1450 d.C.). Estud Atacameños 31, 91-114.

60. Uribe, M. 2012. La prehistoria de Atacama. In: Aldunate, C (Ed), Atacama. Museo Chileno de Arte Precolombino, Santiago, pp. 54-109.

61. Uribe, M., Santana-Sagredo, F., Maturana, A., Flores, S., Agüero, C. 2016. San Pedro de Atacama y la cuestión Tiwanaku en el norte de Chile: Impresiones a 
partir de un clásico estudio ceramioc y la evidencia bioarqueológica actual. Chungará 48, 173-198.

62. Zazzo, A. 2014. Bone and enamel carbonate diagenesis: A radiocarbon perspective. Palaeogeogr, Palaeoclimatol, Palaeoecol 416, 168-178.

63. Zlatar V. 1984. Cementerio Prehispánico Pica-8. Universidad de Antofagasta, Antofagasta.

\section{Figure Captions}

Fig 1. Map on northern Chile indicating the sites studied here by black dots. The three cultural units analysed here are indicated with dashed circles.

Fig 2. Bivariate plots showing values of $\delta^{13} \mathrm{C}$ and $\delta^{15} \mathrm{~N}$ from different tissues for the cultural groups Antofagasta, Loa-San Pedro, Tarapacá Coast and Tarapacá Inland. a) Bivariate plot showing values of $\delta^{13} \mathrm{C}_{\text {coll }}$ and $\delta^{15} \mathrm{~N}$ from bone collagen. b) Bivariate plot showing values of $\delta^{13} \mathrm{C}_{\mathrm{ap}}$ and $\delta^{15} \mathrm{~N}$ from bone apatite

Fig 3. a) Bivariate plots showing values of $\delta^{13} \mathrm{C}$ and $\delta^{18} \mathrm{O}$ from different tissues for the cultural groups Antofagasta, Loa-San Pedro, Tarapacá Coast and Tarapacá Inland. a) Bivariate plot showing values of $\delta^{13} \mathrm{C}_{e n}$ and $\delta^{18} \mathrm{O}_{\text {en }}$ from tooth enamel. b) Bivariate plot showing values of $\delta^{13} \mathrm{C}_{\mathrm{bn}}$ and $\delta^{18} \mathrm{O}_{\mathrm{bn}}$ from bone apatite

Fig 4. Bivariate plot showing values of $\delta^{13} \mathrm{C}$ and $\delta^{15} \mathrm{~N}$ as averages and standard deviations for modern floral and faunal resources by Tieszen and Chapman (1992) and Díaz et al. (2016), as well as archaeological faunal resources by López et al. (2017) as compared with dietary $\delta^{13} \mathrm{C}$ and $\delta^{15} \mathrm{~N}$ values for the cultural groups Antofagasta, LoaSan Pedro, Tarapacá Coast and Tarapacá Inland. These dietary $\delta^{13} \mathrm{C}$ and $\delta^{15} \mathrm{~N}$ values were estimated using an offset of +5 and +4 for $\Delta{ }^{13} \mathrm{C}_{\text {diet-collagen }}$ and $\Delta{ }^{15} \mathrm{~N}_{\text {diet-collagen }}$ in humans, respectively. Modern terrestrial floral and faunal $\delta^{13} \mathrm{C}$ values were corrected for fossil carbon depletion to pre-industrial $\delta^{13} \mathrm{C}_{\mathrm{CO} 2}$ values considering $1.5 \%$ (Marino and McElroy, 1991).

Fig 5. Bivariate plots showing isotope values of carbon, nitrogen and oxygen for individuals that were sampled for both tooth and bone tissues for the cultural groups Antofagasta, Loa-San Pedro, Tarapacá Coast and Tarapacá Inland. Non-local individuals are indicated by their inventory number a) Bivariate plot showing values of $\delta^{13} \mathrm{C}_{\mathrm{en}}$ and $\delta^{18} \mathrm{O}_{\mathrm{en}}$ from tooth enamel. b) Bivariate plot showing values of $\delta^{13} \mathrm{C}_{\mathrm{bn}}$ and $\delta^{18} \mathrm{O}_{\mathrm{bn}}$ from bone apatite. c) Bivariate plot showing values of $\delta^{13} \mathrm{C}_{\text {coll }}$ and $\delta^{15} \mathrm{~N}$ from bone collagen. d) Bivariate plot showing values of $\delta^{13} \mathrm{C}_{\mathrm{ap}}$ and $\delta^{15} \mathrm{~N}$ from bone apatite. 





a)

\section{Bone collagen}

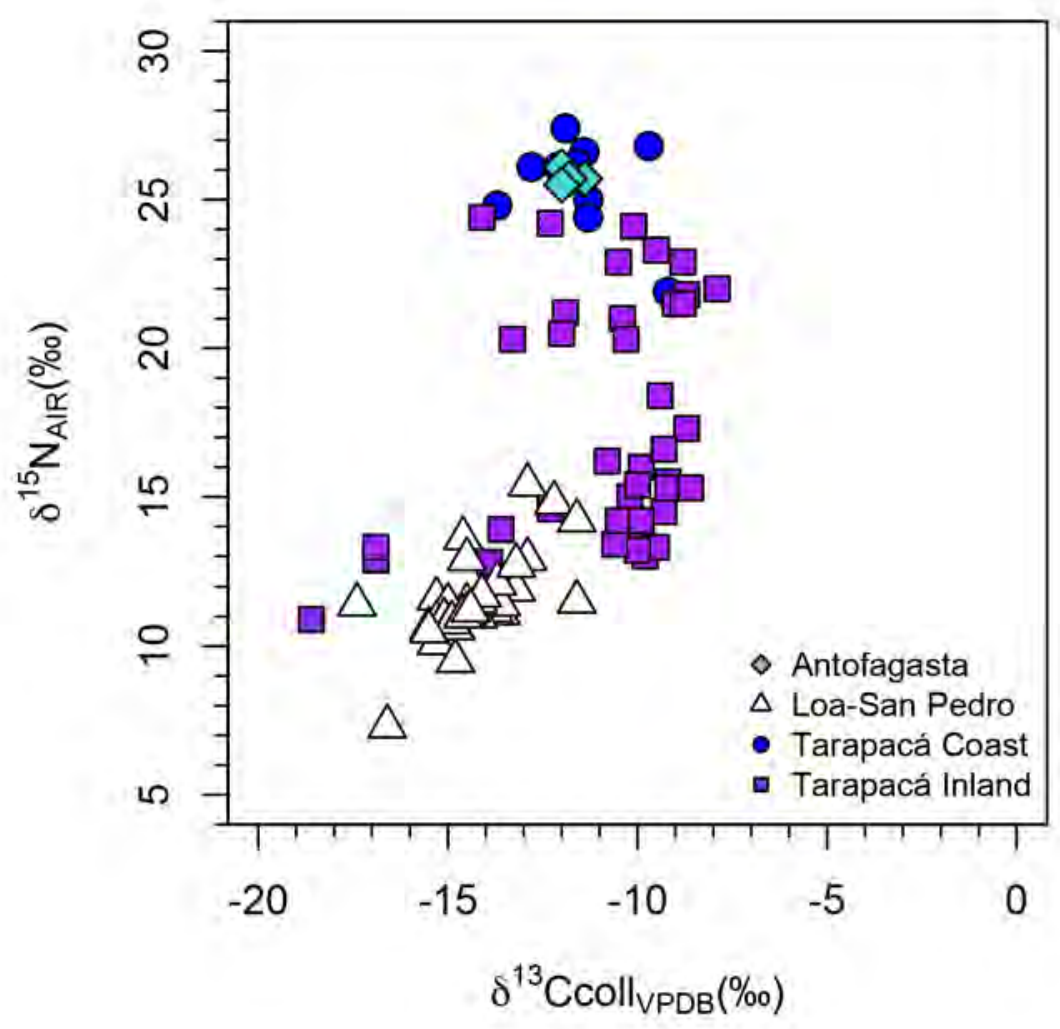

b)

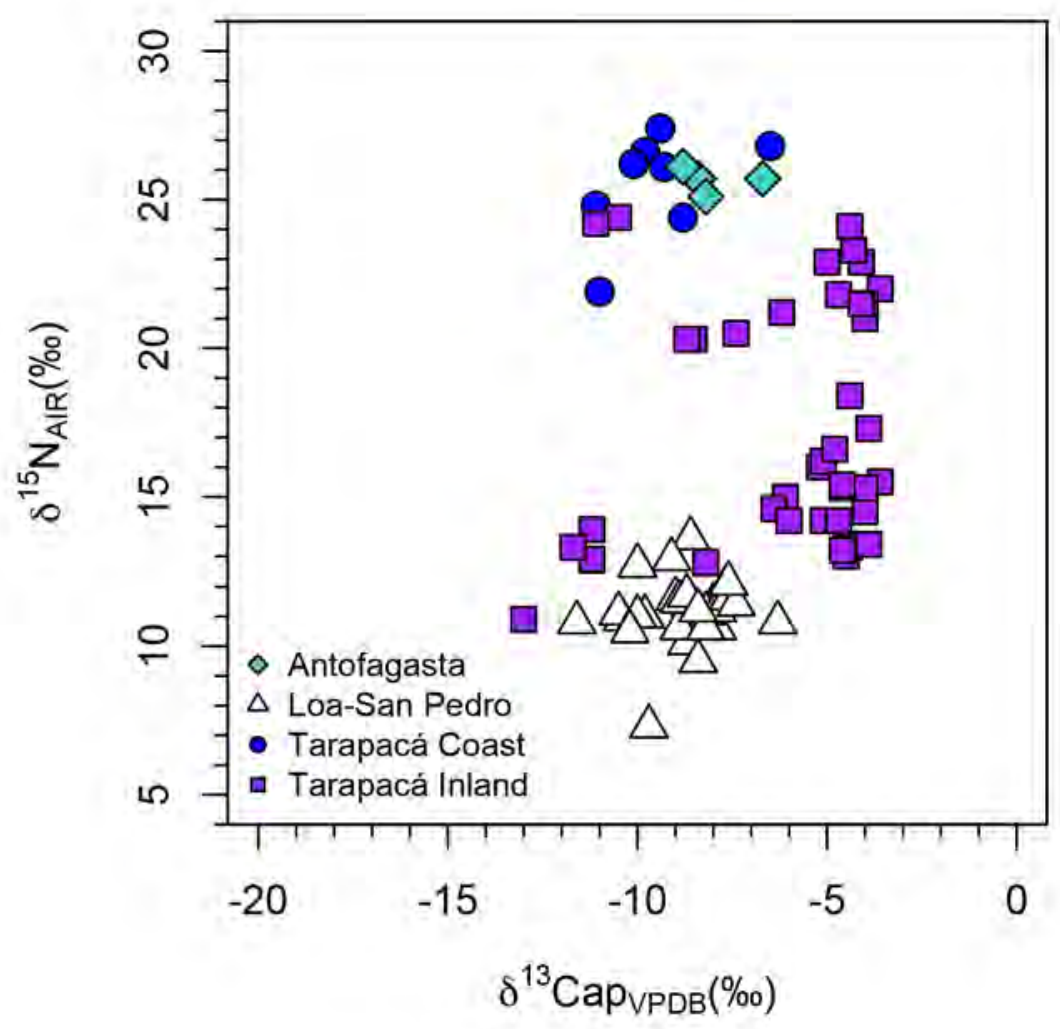


a)

Tooth Enamel

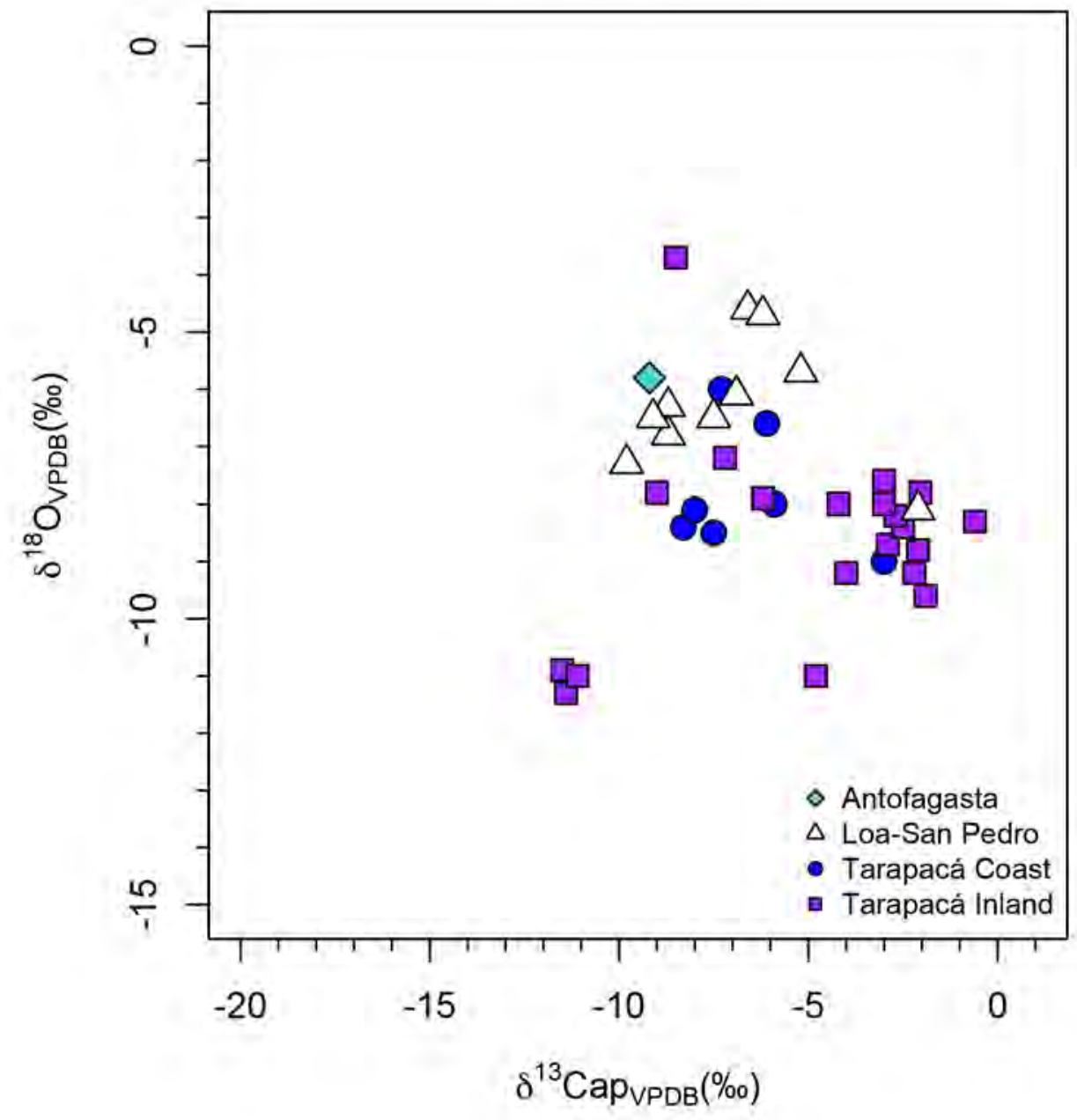

b)

Bone Apatite

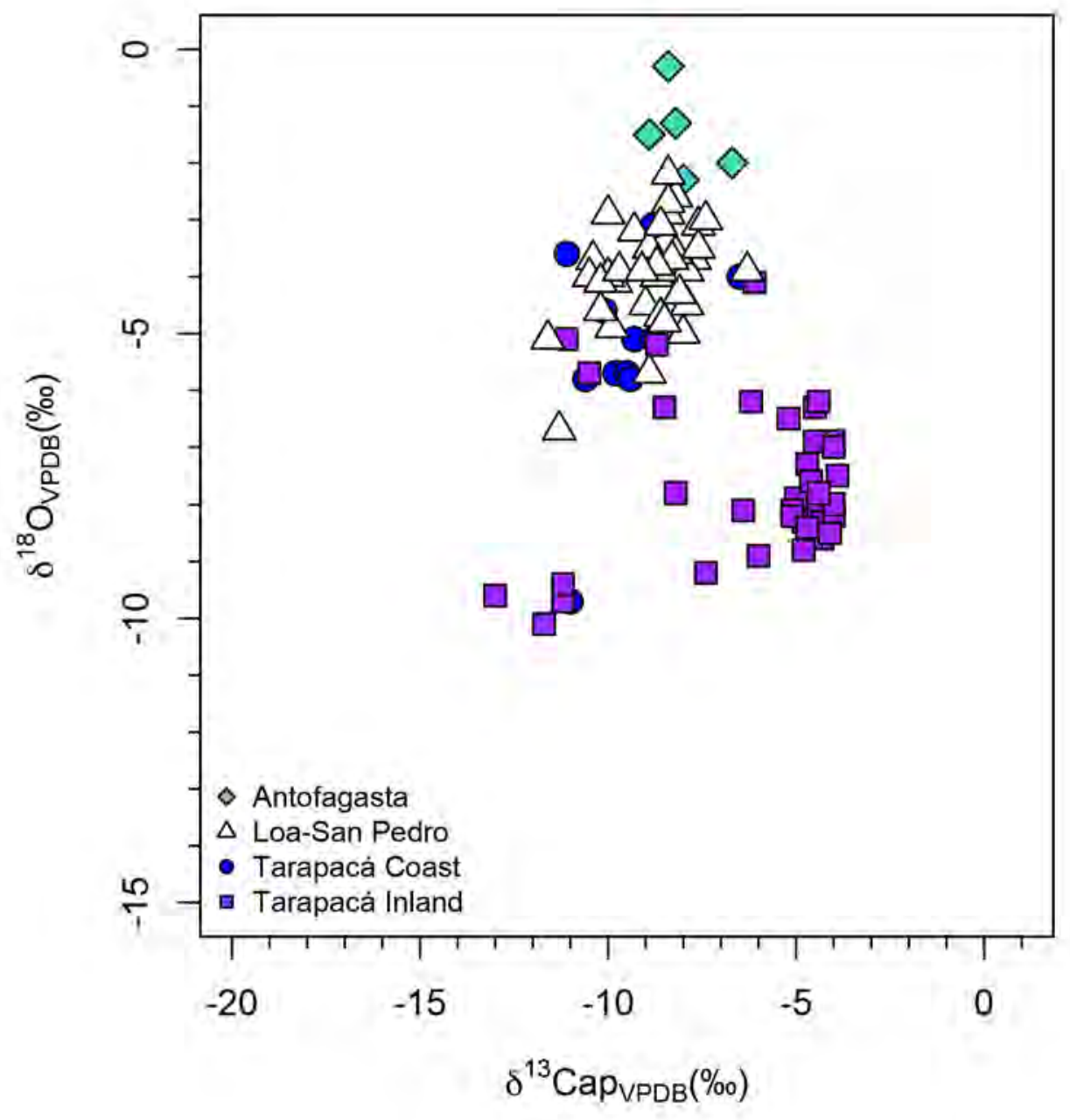




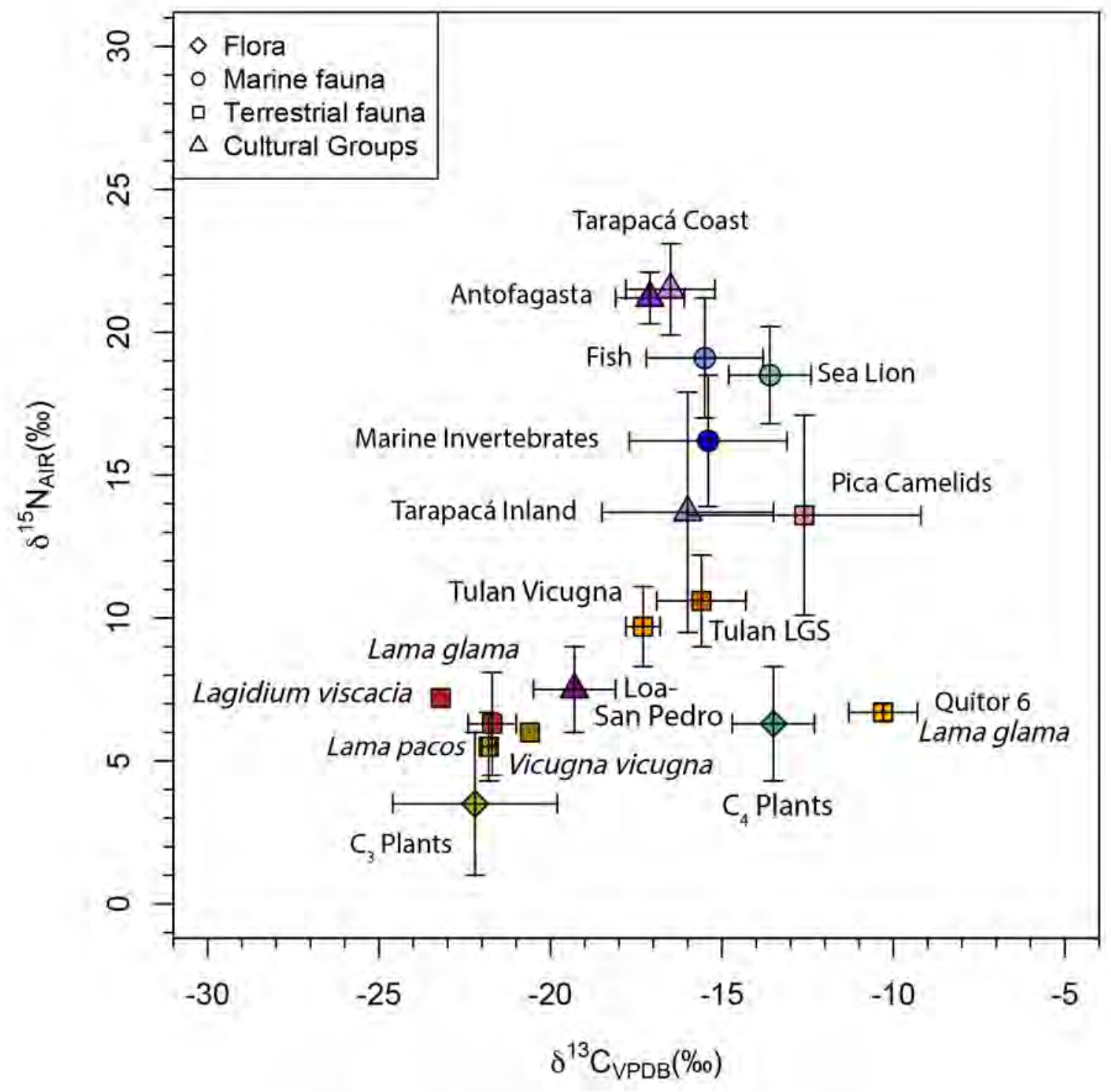


a)

Tooth Enamel

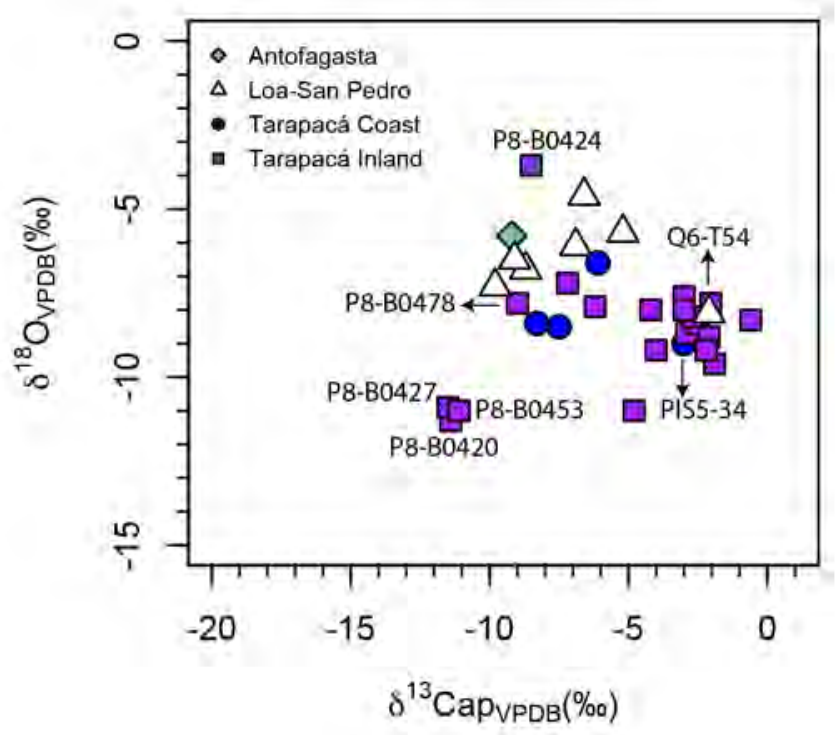

c) Bone collagen

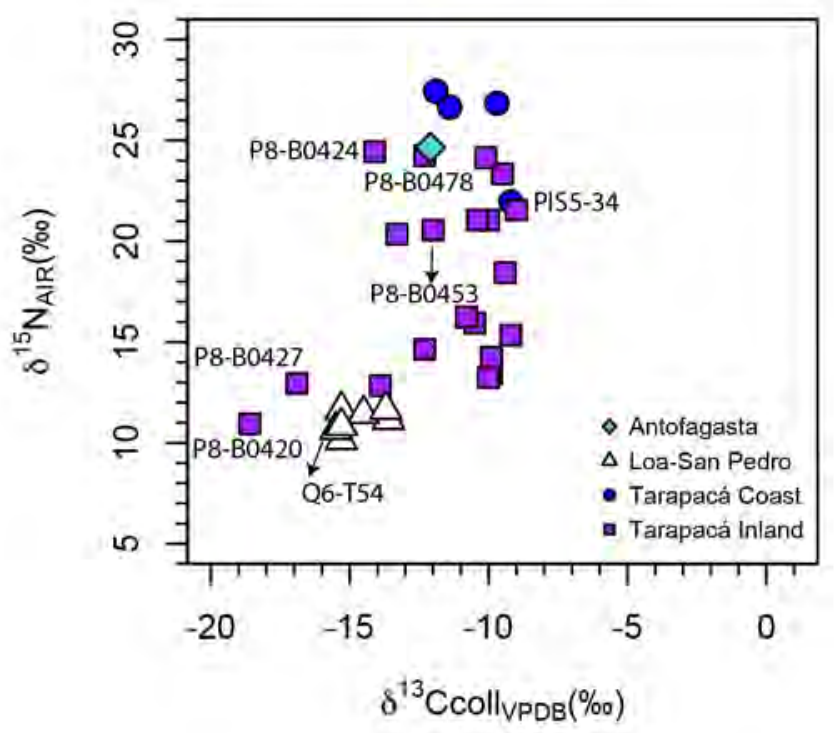

b) Bone Apatite

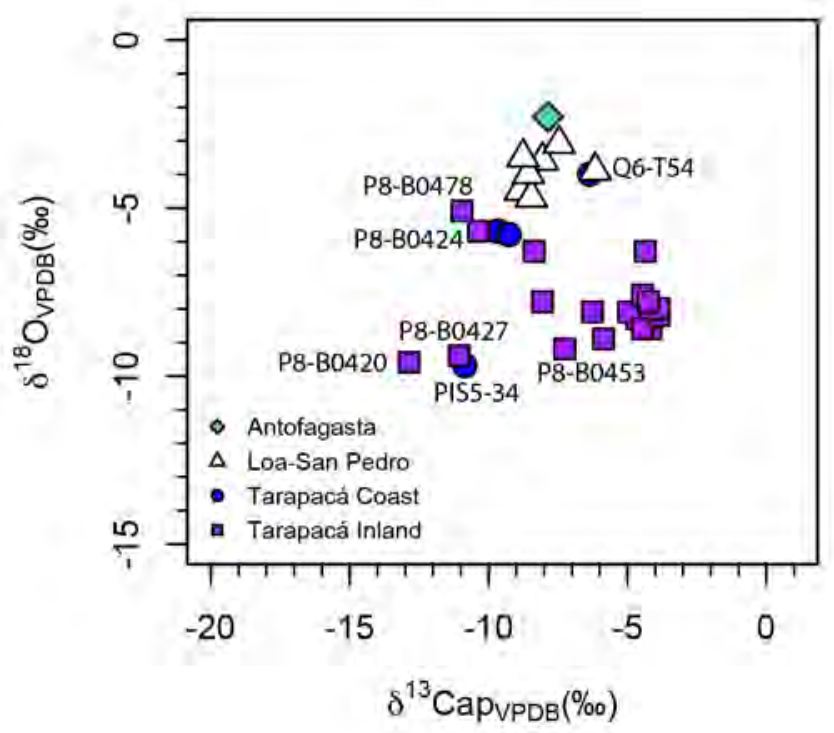

d)

Bone apatite

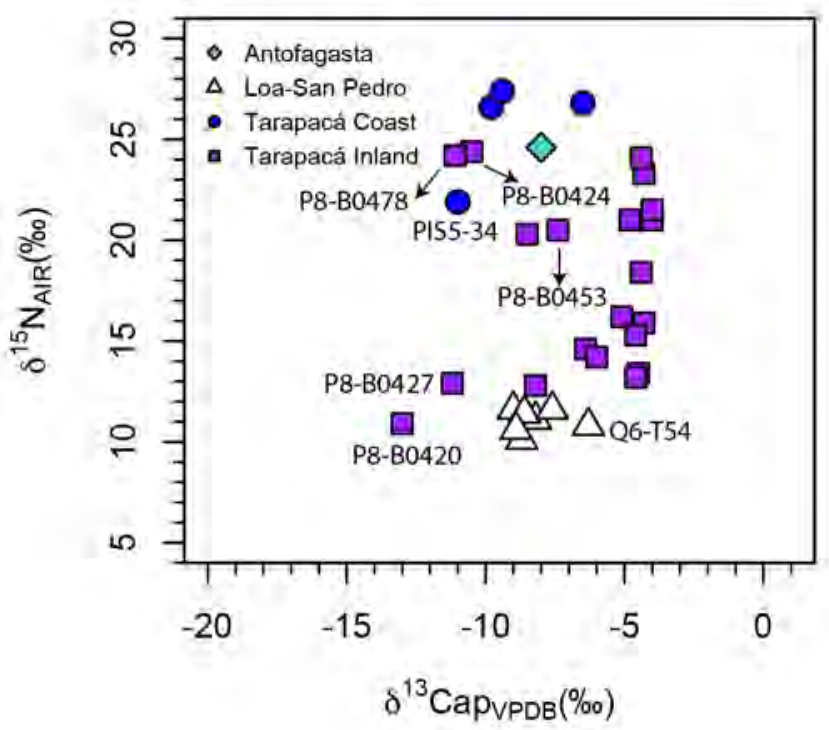




\begin{tabular}{|c|c|c|c|c|c|c|c|c|c|c|c|c|c|}
\hline $\begin{array}{l}\text { Cultural } \\
\text { Association }\end{array}$ & Location & Site & $\mathbf{N}^{0}$ & Sex & Sample & Sector & $\delta^{13} C_{\text {en }}$ & $\delta^{18} O_{\text {en }}$ & $\delta^{13} C_{b n}$ & $\delta{ }^{18} O_{b n}$ & $\delta^{13} C_{\text {coll }}$ & $\delta^{15} \mathrm{~N}$ & $\mathrm{C} / \mathrm{N}$ \\
\hline Antofagasta & Coast & Autoclub & $\begin{array}{l}\mathrm{AC} \\
4631 \mathrm{~A}\end{array}$ & $\mathrm{U}$ & Rib & - & -9.2 & -5.8 & -8 & -2.3 & -12.1 & 24.6 & 3.4 \\
\hline Antofagasta & Coast & Autoclub & $\begin{array}{l}\mathrm{AC} \\
4628 . \mathrm{A}\end{array}$ & $\mathrm{F}$ & $\mathrm{M}^{3}, \mathrm{Rib}$ & - & - & - & -8.4 & -0.3 & -11.4 & 25.7 & 3.2 \\
\hline Antofagasta & Coast & Autoclub & $\begin{array}{l}\mathrm{AC} \\
4638 . \mathrm{C} 1\end{array}$ & $M$ & Rib & - & - & - & -8.8 & -1.3 & -12.0 & 26.1 & 3.3 \\
\hline Antofagasta & Coast & Autoclub & AC 4641 & $\mathrm{M}$ & Ulna & - & - & - & -6.7 & -2.0 & -11.8 & 25.7 & 3.3 \\
\hline Antofagasta & Coast & Autoclub & $\begin{array}{l}A C \\
5052 B\end{array}$ & $U$ & Rib & - & - & - & -8.2 & -1.3 & -11.3 & 25.1 & 3.2 \\
\hline $\begin{array}{l}\text { Loa-San } \\
\text { Pedro }\end{array}$ & Inland & Quitor 6 & Q6T02 & $\mathrm{M}$ & Rib & - & - & - & $-7.7^{*}$ & $-3.7^{*}$ & $-13.2^{*}$ & $11.9^{*}$ & $3.2^{*}$ \\
\hline $\begin{array}{l}\text { Loa-San } \\
\text { Pedro }\end{array}$ & Inland & Quitor 6 & Q6T07 & $\mathrm{M}$ & $\mathrm{M}_{3}, \mathrm{Rib}$ & - & -7.5 & -6.5 & -9.9 & -4.9 & -17.6 & 19.5 & 5.9 \\
\hline $\begin{array}{l}\text { Loa-San } \\
\text { Pedro }\end{array}$ & Inland & Quitor 6 & Q6T09 & $\mathrm{F}$ & Rib & - & - & - & -7.9 & -3.9 & -14.8 & 10.6 & 3.4 \\
\hline $\begin{array}{l}\text { Loa-San } \\
\text { Pedro }\end{array}$ & Inland & Quitor 6 & Q6T11 & $\mathrm{M}$ & $\mathrm{M}_{2}$, Rib & - & -9.8 & -7.3 & $-9.0^{*}$ & $-4.5^{*}$ & $-15.3^{*}$ & $11.6^{*}$ & $3.2^{*}$ \\
\hline $\begin{array}{l}\text { Loa-San } \\
\text { Pedro }\end{array}$ & Inland & Quitor 6 & Q6T19 & $\mathrm{M}$ & Rib & - & - & - & $-8.0^{*}$ & $-5.0^{*}$ & $-17.4^{*}$ & $11.4^{*}$ & 3.8 \\
\hline $\begin{array}{l}\text { Loa-San } \\
\text { Pedro }\end{array}$ & Inland & Quitor 6 & Q6T21 & $\mathrm{F}$ & Rib & - & - & - & -9.3 & -3.2 & -15.7 & 12.0 & 3.8 \\
\hline $\begin{array}{l}\text { Loa-San } \\
\text { Pedro }\end{array}$ & Inland & Quitor 6 & Q6T30 & $\mathrm{F}$ & $\mathrm{M}_{3}, \mathrm{Rib}$ & - & -6.9 & -6.1 & -8.2 & -3.6 & -13.6 & 11.1 & 3.3 \\
\hline $\begin{array}{l}\text { Loa-San } \\
\text { Pedro }\end{array}$ & Inland & Quitor 6 & Q6T31 & $\mathrm{M}$ & $\mathrm{M}_{3}, \mathrm{Rib}$ & - & -6.6 & -4.6 & $-8.6^{*}$ & $-4.7^{*}$ & $-14.5^{*}$ & $11.4^{*}$ & $3.2^{*}$ \\
\hline $\begin{array}{l}\text { Loa-San } \\
\text { Pedro }\end{array}$ & Inland & Quitor 6 & Q6T34 & $\mathrm{F}$ & $\mathrm{M}^{2}, \mathrm{Rib}$ & - & -6.2 & -4.7 & -8.5 & -4.8 & - & - & - \\
\hline $\begin{array}{l}\text { Loa-San } \\
\text { Pedro }\end{array}$ & Inland & Quitor 6 & Q6T35 & $M$ & $\mathrm{M}_{2}, \mathrm{Rib}$ & - & -8.7 & -6.8 & $-8.7^{*}$ & $-4.0^{*}$ & $-15.3^{*}$ & $10.1^{*}$ & $3.4^{*}$ \\
\hline $\begin{array}{l}\text { Loa-San } \\
\text { Pedro }\end{array}$ & Inland & Quitor 6 & Q6T36 & $\mathrm{M}$ & Rib & - & - & - & $-7.9^{*}$ & $-4.5^{*}$ & $-13.8^{*}$ & $11.2^{*}$ & $3.4^{*}$ \\
\hline Loa-San & Inland & Quitor 6 & Q6T39 & $\mathrm{F}$ & Rib & - & - & - & $-8.1^{*}$ & $-4.3^{*}$ & - & - & - \\
\hline
\end{tabular}




\begin{tabular}{|c|c|c|c|c|c|c|c|c|c|c|c|c|c|}
\hline Pedro & & & & & & & & & & & & & \\
\hline $\begin{array}{l}\text { Loa-San } \\
\text { Pedro }\end{array}$ & Inland & Quitor 6 & Q6T40 & $F$ & $\mathrm{M}^{3}, \mathrm{Rib}$ & - & -8.7 & -6.3 & - & - & -15.0 & 11.4 & 3.6 \\
\hline $\begin{array}{l}\text { Loa-San } \\
\text { Pedro }\end{array}$ & Inland & Quitor 6 & Q6T42 & $F$ & Rib & - & - & - & $-9.8^{*}$ & $-4.1^{*}$ & $-14.2^{*}$ & $11.0^{*}$ & $3.2^{*}$ \\
\hline $\begin{array}{l}\text { Loa-San } \\
\text { Pedro }\end{array}$ & Inland & Quitor 6 & Q6T45 & $\mathrm{U}$ & Rib & - & - & - & $-8.4^{*}$ & $-2.9^{*}$ & $-14.8^{*}$ & $9.5^{*}$ & $3.2^{*}$ \\
\hline $\begin{array}{l}\text { Loa-San } \\
\text { Pedro }\end{array}$ & Inland & Quitor 6 & Q6T47 & $F$ & $\mathrm{M}_{3}$, Rib & - & -9.1 & -6.5 & $-8.9^{*}$ & $-3.5^{*}$ & $-15.5^{*}$ & $10.6^{*}$ & $3.3^{*}$ \\
\hline $\begin{array}{l}\text { Loa-San } \\
\text { Pedro }\end{array}$ & Inland & Quitor 6 & Q6T50 & $U$ & Rib & - & - & - & $-8.2^{*}$ & $-2.6^{*}$ & $-14.8^{*}$ & $10.6^{*}$ & $3.3^{*}$ \\
\hline $\begin{array}{l}\text { Loa-San } \\
\text { Pedro }\end{array}$ & Inland & Quitor 6 & Q6T51 & $M$ & $\begin{array}{l}\mathrm{M}^{3} \text {,Phalang } \\
\mathrm{e}\end{array}$ & - & -5.2 & -5.7 & -7.6 & -3.1 & -13.7 & 11.6 & 3.3 \\
\hline $\begin{array}{l}\text { Loa-San } \\
\text { Pedro }\end{array}$ & Inland & Quitor 6 & Q6T52 & $F$ & Rib & - & - & - & $-8.6^{*}$ & $-3.9^{*}$ & $-11.6^{*}$ & $11.5^{\star}$ & $3.2^{*}$ \\
\hline $\begin{array}{l}\text { Loa-San } \\
\text { Pedro }\end{array}$ & Inland & Quitor 6 & Q6T54 & $F$ & Skull & - & -2.1 & -8.1 & -6.3 & -3.9 & $-15.3^{*}$ & $10.8^{*}$ & $3.5^{*}$ \\
\hline $\begin{array}{l}\text { Loa-San } \\
\text { Pedro }\end{array}$ & Inland & Catarpe 1 & $\begin{array}{l}\text { CAT1- } \\
763\end{array}$ & $F$ & Skull & - & - & - & -7.4 & -3.0 & -13.6 & 11.4 & 3.4 \\
\hline $\begin{array}{l}\text { Loa-San } \\
\text { Pedro }\end{array}$ & Inland & Catarpe 1 & $\begin{array}{l}\text { CAT1- } \\
764 \\
\end{array}$ & $M$ & Skull & - & - & - & - & - & -12.9 & 12.9 & 3.2 \\
\hline $\begin{array}{l}\text { Loa-San } \\
\text { Pedro }\end{array}$ & Inland & Catarpe 1 & $\begin{array}{l}\text { CAT1- } \\
2397\end{array}$ & $\mathrm{~F}$ & Skull & - & - & - & -7.6 & -3.5 & -13.7 & 12.1 & 3.3 \\
\hline $\begin{array}{l}\text { Loa-San } \\
\text { Pedro }\end{array}$ & Inland & Caspana & CAS12 & $F$ & Skull & - & - & - & - & - & -12.2 & 14.8 & 3.3 \\
\hline $\begin{array}{l}\text { Loa-San } \\
\text { Pedro }\end{array}$ & Inland & Caspana & CAS61 & $F$ & Skull & - & - & - & - & - & -11.6 & 14.2 & 3.3 \\
\hline $\begin{array}{l}\text { Loa-San } \\
\text { Pedro }\end{array}$ & Inland & Caspana & CAS66 & $F$ & Skull & - & - & - & - & - & -12.9 & 15.4 & 3.3 \\
\hline $\begin{array}{l}\text { Loa-San } \\
\text { Pedro }\end{array}$ & Inland & Toconce & TOC76 & $F$ & Skull & - & - & - & -8.9 & -5.7 & -14.2 & 11.5 & 3.3 \\
\hline $\begin{array}{l}\text { Loa-San } \\
\text { Pedro }\end{array}$ & Inland & $\begin{array}{l}\text { Toconao } \\
\text { Oriente }\end{array}$ & TOT1 & $F$ & Rib & - & - & - & -10.4 & -3.7 & -15.1 & 10.9 & 3.6 \\
\hline $\begin{array}{l}\text { Loa-San } \\
\text { Pedro }\end{array}$ & Inland & $\begin{array}{l}\text { Toconao } \\
\text { Oriente }\end{array}$ & TOT2 & $F$ & Rib & - & - & - & -10.5 & -4.0 & -14.5 & 11.1 & 3.2 \\
\hline
\end{tabular}




\begin{tabular}{|c|c|c|c|c|c|c|c|c|c|c|c|c|c|}
\hline $\begin{array}{l}\text { Loa-San } \\
\text { Pedro }\end{array}$ & Inland & $\begin{array}{l}\text { Toconao } \\
\text { Oriente }\end{array}$ & TOT3 & $M$ & Rib & - & - & - & -8.3 & -3.7 & - & - & - \\
\hline $\begin{array}{l}\text { Loa-San } \\
\text { Pedro }\end{array}$ & Inland & $\begin{array}{l}\text { Toconao } \\
\text { Oriente }\end{array}$ & TOT4 & $M$ & Clavicle & - & - & - & -8.7 & -3.8 & -14.1 & 11.7 & 3.4 \\
\hline $\begin{array}{l}\text { Loa-San } \\
\text { Pedro }\end{array}$ & Inland & $\begin{array}{l}\text { Toconao } \\
\text { Oriente }\end{array}$ & TOT5 & $\mathrm{M}$ & Rib & - & - & - & -11.6 & -5.1 & -14.9 & 10.8 & 3.3 \\
\hline $\begin{array}{l}\text { Loa-San } \\
\text { Pedro }\end{array}$ & Inland & $\begin{array}{l}\text { Toconao } \\
\text { Oriente }\end{array}$ & TOT6 & $\mathrm{F}$ & Rib & - & - & - & -10.0 & -4.0 & -14.6 & 11.0 & 3.3 \\
\hline $\begin{array}{l}\text { Loa-San } \\
\text { Pedro }\end{array}$ & Inland & $\begin{array}{l}\text { Toconao } \\
\text { Oriente }\end{array}$ & TOT7 & $\mathrm{F}$ & Phalange & - & - & - & -8.4 & -2.2 & -14.4 & 11.2 & 3.2 \\
\hline $\begin{array}{l}\text { Loa-San } \\
\text { Pedro }\end{array}$ & Inland & $\begin{array}{l}\text { Toconao } \\
\text { Oriente }\end{array}$ & TOT8 & $F$ & Rib & - & - & - & -10.2 & -4.1 & -15.5 & 10.5 & 3.7 \\
\hline $\begin{array}{l}\text { Loa-San } \\
\text { Pedro }\end{array}$ & Inland & $\begin{array}{l}\text { Toconao } \\
\text { Oriente }\end{array}$ & TOT9 & $M$ & Skull & - & - & - & -8.4 & -2.7 & - & - & - \\
\hline $\begin{array}{l}\text { Loa-San } \\
\text { Pedro }\end{array}$ & Inland & $\begin{array}{l}\text { Toconao } \\
\text { Oriente }\end{array}$ & $\begin{array}{l}\text { TOT11.C } \\
1\end{array}$ & $M$ & Skull & - & - & - & -11.3 & -6.7 & - & - & - \\
\hline $\begin{array}{l}\text { Loa-San } \\
\text { Pedro }\end{array}$ & Inland & $\begin{array}{l}\text { Toconao } \\
\text { Oriente }\end{array}$ & TOT12 & $M$ & Rib & - & - & - & -10.0 & -2.9 & -13.2 & 12.7 & 3.2 \\
\hline $\begin{array}{l}\text { Loa-San } \\
\text { Pedro }\end{array}$ & Inland & $\begin{array}{l}\text { Toconao } \\
\text { Oriente }\end{array}$ & T013 & $\mathrm{F}$ & Skull & - & - & - & -10.2 & -4.6 & -16.6 & 7.9 & 4.2 \\
\hline $\begin{array}{l}\text { Loa-San } \\
\text { Pedro }\end{array}$ & Inland & $\begin{array}{l}\text { Toconao } \\
\text { Oriente }\end{array}$ & TO14 & $M$ & Skull & - & - & - & -9.7 & -3.9 & -16.6 & 7.3 & 3.6 \\
\hline $\begin{array}{l}\text { Loa-San } \\
\text { Pedro }\end{array}$ & Inland & $\begin{array}{l}\text { Toconao } \\
\text { Oriente }\end{array}$ & T015 & $\mathrm{F}$ & Skull & - & - & - & -8.6 & -3.1 & -14.6 & 13.6 & 3.4 \\
\hline $\begin{array}{l}\text { Loa-San } \\
\text { Pedro }\end{array}$ & Inland & $\begin{array}{l}\text { Toconao } \\
\text { Oriente }\end{array}$ & T016 & $M$ & Skull & - & - & - & -9.1 & -3.9 & -14.5 & 12.9 & 3.6 \\
\hline $\begin{array}{l}\text { Pica- } \\
\text { Tarapacá }\end{array}$ & Coast & $\begin{array}{l}\text { Pisagua- } \\
\text { Uhle }\end{array}$ & PIS286 & $U$ & $\mathrm{M}^{2}$, skull & $\begin{array}{l}\text { Cemen } \\
\text { terio H }\end{array}$ & -7.3 & -6.0 & -10.6 & -5.8 & - & - & - \\
\hline $\begin{array}{l}\text { Pica- } \\
\text { Tarapacá }\end{array}$ & Coast & $\begin{array}{l}\text { Pisagua- } \\
\text { Uhle }\end{array}$ & PIS279 & $\mathrm{U}$ & Skull & $\begin{array}{l}\text { Cemen } \\
\text { terio H }\end{array}$ & - & - & - & - & -12.8 & 26.1 & 3.6 \\
\hline $\begin{array}{l}\text { Pica- } \\
\text { Tarapacá }\end{array}$ & Coast & $\begin{array}{l}\text { Pisagua- } \\
\text { Uhle }\end{array}$ & PIS302 & $M$ & $\mathrm{M}^{2}$, skull & $\begin{array}{l}\text { Cemen } \\
\text { terio A }\end{array}$ & -12.9 & -8.0 & -9.8 & -5.7 & -11.4 & 26.6 & 3.3 \\
\hline $\begin{array}{l}\text { Pica- } \\
\text { Tarapacá }\end{array}$ & Coast & $\begin{array}{l}\text { Pisagua- } \\
\text { Uhle }\end{array}$ & PIS344 & $M$ & $\mathrm{M}^{2}$, skull & $\begin{array}{l}\text { Cemen } \\
\text { terio } \mathrm{H}\end{array}$ & -5.9 & -8.0 & - & - & -11.3 & 25.0 & 3.3 \\
\hline $\begin{array}{l}\text { Pica- } \\
\text { Tarapacá }\end{array}$ & Coast & $\begin{array}{l}\text { Pisagua } \\
\text { Gruta }\end{array}$ & PISGC.1 & $\mathrm{U}$ & $\mathrm{M}^{2}$, skull & - & -8.0 & -8.1 & -9.5 & -5.7 & - & - & - \\
\hline
\end{tabular}




\begin{tabular}{|c|c|c|c|c|c|c|c|c|c|c|c|c|c|}
\hline $\begin{array}{l}\text { Pica- } \\
\text { Tarapacá }\end{array}$ & Coast & $\begin{array}{l}\text { Pisagua } \\
\text { Gruta }\end{array}$ & PISGC.2 & $\mathrm{U}$ & $\mathrm{M}^{2}, \mathrm{Rib}$ & - & -7.5 & -8.5 & -9.4 & -5.8 & -11.9 & 27.4 & 3.3 \\
\hline $\begin{array}{l}\text { Pica- } \\
\text { Tarapacá }\end{array}$ & Coast & Pisagua 5 & PIS5 34 & $U$ & $\mathrm{PM}_{2}, \mathrm{Rib}$ & - & -3.0 & -9.0 & -11.0 & -9.7 & -9.2 & 21.9 & 3.2 \\
\hline $\begin{array}{l}\text { Pica- } \\
\text { Tarapacá }\end{array}$ & Coast & $\begin{array}{l}\text { Pisagua } \\
\text { Hospital }\end{array}$ & $\begin{array}{l}\text { PIS } \\
\text { HOSP } \\
\text { SG 247-1 }\end{array}$ & $\mathrm{U}$ & Rib & - & - & - & -10.1 & -4.6 & -11.6 & 26.2 & 3.2 \\
\hline $\begin{array}{l}\text { Pica- } \\
\text { Tarapacá }\end{array}$ & Coast & $\begin{array}{l}\text { Pisagua } \\
\text { Hospital }\end{array}$ & $\begin{array}{l}\text { PIS } \\
\text { HOSP } \\
\text { SG 247-2 }\end{array}$ & $\mathrm{U}$ & Tibia & - & - & - & -9.3 & -5.1 & -12.1 & 26.1 & 3.2 \\
\hline $\begin{array}{l}\text { Pica- } \\
\text { Tarapacá }\end{array}$ & Coast & $\begin{array}{l}\text { Los } \\
\text { Verdes } 5\end{array}$ & LV5 243 & $M$ & Rib & - & - & - & -11.1 & -3.6 & -13.7 & 24.8 & 3.3 \\
\hline $\begin{array}{l}\text { Pica- } \\
\text { Tarapacá }\end{array}$ & Coast & $\begin{array}{l}\text { Bajo } \\
\text { Molle } \\
\text { Edifcio } \\
\text { Armada }\end{array}$ & BM 130 & $M$ & Rib & - & - & - & -8.8 & -3.1 & -11.3 & 24.4 & 3.3 \\
\hline $\begin{array}{l}\text { Pica- } \\
\text { Tarapacá }\end{array}$ & Coast & Iquique & $\begin{array}{l}\text { Alessand } \\
\text { ri } 26\end{array}$ & $M$ & $M^{2}, \mathrm{Rib}$ & - & -6.1 & -6.6 & -6.5 & -4.0 & -9.7 & 26.8 & 3.2 \\
\hline $\begin{array}{l}\text { Pica- } \\
\text { Tarapacá }\end{array}$ & Coast & Iquique & $\begin{array}{l}\text { Tar-Lab } \\
175\end{array}$ & $\mathrm{U}$ & Rib & - & - & - & -8.8 & -5.1 & -16.5 & 27.4 & 4.2 \\
\hline $\begin{array}{l}\text { Pica- } \\
\text { Tarapacá }\end{array}$ & Inland & $\begin{array}{l}\text { San } \\
\text { Lorenzo } \\
\text { de } \\
\text { Tarapacá }\end{array}$ & SLT M1 & $M$ & Phalange & - & - & - & -6.1 & -4.1 & -10.2 & 15.0 & 3.2 \\
\hline $\begin{array}{l}\text { Pica- } \\
\text { Tarapacá }\end{array}$ & Inland & $\begin{array}{l}\text { San } \\
\text { Lorenzo } \\
\text { de } \\
\text { Tarapacá }\end{array}$ & SLT 121 & $\mathrm{~F}$ & Rib & - & - & - & -11.2 & -9.7 & -13.6 & 13.9 & 3.2 \\
\hline $\begin{array}{l}\text { Pica- } \\
\text { Tarapacá }\end{array}$ & Inland & Pica 8 & P8 B0410 & $\mathrm{F}$ & Rib & Sector I & - & - & $-5.0^{*}$ & $-7.9^{*}$ & $-10.5^{*}$ & $22.9^{*}$ & $3.7^{*}$ \\
\hline $\begin{array}{l}\text { Pica- } \\
\text { Tarapacá }\end{array}$ & Inland & Pica 8 & P8 B0413 & $\mathrm{F}$ & $\mathrm{PM}_{2}, \mathrm{Rib}$ & Sector I & $-2.04^{*}$ & $-7.8^{*}$ & $-4.8^{*}$ & $-8.3^{*}$ & $-10.0^{*}$ & $21.0^{*}$ & $4.2^{*}$ \\
\hline $\begin{array}{l}\text { Pica- } \\
\text { Tarapacá }\end{array}$ & Inland & Pica 8 & P8 B0414 & $M$ & Rib & $\begin{array}{l}\text { Sector } \\
\mathrm{B}\end{array}$ & - & - & -3.6 & - & -9.2 & 15.5 & 3.6 \\
\hline $\begin{array}{l}\text { Pica- } \\
\text { Tarapacá }\end{array}$ & Inland & Pica 8 & P8 B0419 & $F$ & $\mathrm{M}_{2}$, Rib & $\begin{array}{l}\text { Sector } \\
\mathrm{G}\end{array}$ & $-2.9^{*}$ & $-8.7^{*}$ & $-4.5^{*}$ & $-6.3^{*}$ & $-9.9^{*}$ & $13.4^{*}$ & $3.3^{*}$ \\
\hline
\end{tabular}




\begin{tabular}{|c|c|c|c|c|c|c|c|c|c|c|c|c|c|}
\hline $\begin{array}{l}\text { Pica- } \\
\text { Tarapacá }\end{array}$ & Inland & Pica 8 & P8 B0420 & $F$ & $\mathrm{M}^{3}, \mathrm{Rib}$ & $\begin{array}{l}\text { Sector } \\
\text { E }\end{array}$ & $-11.4^{*}$ & $-11.3^{*}$ & $-13.0^{*}$ & $-9.6^{*}$ & $-18.6^{*}$ & $10.9^{*}$ & $3.4^{*}$ \\
\hline $\begin{array}{l}\text { Pica- } \\
\text { Tarapacá }\end{array}$ & Inland & Pica 8 & P8 B0421 & $F$ & $M_{3}$, Rib & $\begin{array}{l}\text { Sector } \\
\text { B }\end{array}$ & $-2.5^{*}$ & $-8.4^{*}$ & $-4.3^{*}$ & $-8.6^{*}$ & $-10.5^{*}$ & $15.9^{*}$ & $3.8^{*}$ \\
\hline $\begin{array}{l}\text { Pica- } \\
\text { Tarapacá }\end{array}$ & Inland & Pica 8 & P8 B0422 & $F$ & Rib & Sector I & - & - & -4.1 & -6.9 & -8.8 & 22.9 & 3.6 \\
\hline $\begin{array}{l}\text { Pica- } \\
\text { Tarapacá }\end{array}$ & Inland & Pica 8 & P8 B0423 & $F$ & Rib & $\begin{array}{l}\text { Sector } \\
\text { D }\end{array}$ & - & - & $-6.2^{*}$ & $-6.2^{*}$ & $-11.9^{*}$ & $21.2^{*}$ & $3.5^{*}$ \\
\hline $\begin{array}{l}\text { Pica- } \\
\text { Tarapacá }\end{array}$ & Inland & Pica 8 & P8 B0424 & $F$ & $\mathrm{M}^{2}, \mathrm{Rib}$ & Sector I & $-8.5^{*}$ & $-3.7^{*}$ & $-10.5^{\star}$ & $-5.7^{*}$ & $-14.1^{*}$ & $24.4^{*}$ & $3.6^{*}$ \\
\hline $\begin{array}{l}\text { Pica- } \\
\text { Tarapacá }\end{array}$ & Inland & Pica 8 & P8 B0426 & $F$ & $\mathrm{M}_{2}, \mathrm{Rib}$ & Sector I & $-4.2^{*}$ & $-8.0^{*}$ & $-4.4^{*}$ & $-8.0^{*}$ & $-9.4^{*}$ & $18.4^{*}$ & $3.4^{*}$ \\
\hline $\begin{array}{l}\text { Pica- } \\
\text { Tarapacá }\end{array}$ & Inland & Pica 8 & P8 B0427 & $M$ & $M^{2}, \mathrm{Rib}$ & $\begin{array}{l}\text { Sector } \\
\text { D }\end{array}$ & $-11.5^{\star}$ & $-10.9^{*}$ & $-11.2^{*}$ & $-9.4^{*}$ & $-16.9^{*}$ & $12.9^{*}$ & $3.9^{*}$ \\
\hline $\begin{array}{l}\text { Pica- } \\
\text { Tarapacá }\end{array}$ & Inland & Pica 8 & P8 B0428 & $\mathrm{F}$ & $M^{3}$, Rib & Sector I & $-2.1^{*}$ & $-8.8^{*}$ & $-4.3^{*}$ & $-8.3^{*}$ & $-9.5^{*}$ & $23.3^{*}$ & $3.6^{*}$ \\
\hline $\begin{array}{l}\text { Pica- } \\
\text { Tarapacá }\end{array}$ & Inland & Pica 8 & P8 B0430 & $F$ & Rib & $\begin{array}{l}\text { Sector } \\
\mathrm{F}\end{array}$ & - & - & $-4.0^{*}$ & $-6.9^{*}$ & $-9.3^{*}$ & $14.5^{*}$ & $3.2^{*}$ \\
\hline $\begin{array}{l}\text { Pica- } \\
\text { Tarapacá }\end{array}$ & Inland & Pica 8 & P8 B0431 & $M$ & $\mathrm{M}^{3}, \mathrm{Rib}$ & $\begin{array}{l}\text { Sector } \\
\text { G }\end{array}$ & $-6.2^{*}$ & $-7.9^{*}$ & $-8.2^{*}$ & $-7.8^{*}$ & $-13.9^{*}$ & $12.8^{*}$ & $3.3^{*}$ \\
\hline $\begin{array}{l}\text { Pica- } \\
\text { Tarapacá }\end{array}$ & Inland & Pica 8 & P8 B0432 & $F$ & $M^{3}, \mathrm{Rib}$ & - & $-4.0^{*}$ & $-9.2^{*}$ & $-6.4^{*}$ & $-8.1^{*}$ & $-12.3^{*}$ & $14.6^{*}$ & $3.7^{*}$ \\
\hline $\begin{array}{l}\text { Pica- } \\
\text { Tarapacá }\end{array}$ & Inland & Pica 8 & P8 B0433 & $F$ & Rib & $\begin{array}{l}\text { Sector } \\
\text { D }\end{array}$ & - & - & -5.2 & -6.5 & -9.9 & 16.0 & 3.2 \\
\hline $\begin{array}{l}\text { Pica- } \\
\text { Tarapacá }\end{array}$ & Inland & Pica 8 & P8 B0435 & $M$ & Rib & $\begin{array}{l}\text { Sector } \\
\text { G }\end{array}$ & - & - & $-4.5^{*}$ & $-6.9^{*}$ & $-9.8^{*}$ & $13.0^{*}$ & $3.3^{*}$ \\
\hline $\begin{array}{l}\text { Pica- } \\
\text { Tarapacá }\end{array}$ & Inland & Pica 8 & P8 B0438 & $\mathrm{F}$ & Rib & Sector I & - & - & -4.7 & -7.3 & -8.7 & 21.8 & 3.5 \\
\hline $\begin{array}{l}\text { Pica- } \\
\text { Tarapacá }\end{array}$ & Inland & Pica 8 & P8 B0439 & $F$ & $\mathrm{M}^{3}, \mathrm{Rib}$ & $\begin{array}{l}\text { Sector } \\
\mathrm{A}\end{array}$ & $-7.2^{*}$ & $-7.2^{*}$ & $-5.1^{*}$ & $-8.1^{*}$ & $-10.8^{*}$ & $16.2^{*}$ & $3.3^{*}$ \\
\hline $\begin{array}{l}\text { Pica- } \\
\text { Tarapacá }\end{array}$ & Inland & Pica 8 & P8 B0440 & $M$ & $\mathrm{M}^{2}, \mathrm{Rib}$ & $\begin{array}{l}\text { Sector } \\
\text { B }\end{array}$ & $-0.6^{*}$ & $-8.3^{*}$ & $-4.6^{*}$ & $-8.6^{*}$ & $-9.2^{*}$ & $15.3^{*}$ & $3.3^{*}$ \\
\hline $\begin{array}{l}\text { Pica- } \\
\text { Tarapacá }\end{array}$ & Inland & Pica 8 & P8 B0441 & $M$ & $\mathrm{M}_{2}, \mathrm{Rib}$ & $\begin{array}{l}\text { Sector } \\
\text { D }\end{array}$ & $0.8^{*}$ & $-8.6^{*}$ & $-4.4^{*}$ & $-6.9^{*}$ & $-9.9^{*}$ & $19.6^{*}$ & $3.6^{*}$ \\
\hline $\begin{array}{l}\text { Pica- } \\
\text { Tarapacá }\end{array}$ & Inland & Pica 8 & P8 B0442 & $F$ & Rib & $\begin{array}{l}\text { Sector } \\
\mathrm{F}\end{array}$ & - & - & -4.0 & -7.0 & -8.6 & 15.3 & 3.2 \\
\hline
\end{tabular}




\begin{tabular}{|c|c|c|c|c|c|c|c|c|c|c|c|c|c|}
\hline $\begin{array}{l}\text { Pica- } \\
\text { Tarapacá }\end{array}$ & Inland & Pica 8 & P8 B0444 & $M$ & Rib & $\begin{array}{l}\text { Sector } \\
\text { F }\end{array}$ & - & - & -4.6 & - & -10.0 & 15.4 & 3.4 \\
\hline $\begin{array}{l}\text { Pica- } \\
\text { Tarapacá }\end{array}$ & Inland & Pica 8 & P8 B0447 & $M$ & $\mathrm{M}^{2}, \mathrm{Rib}$ & Sector I & $-1.9^{*}$ & $-9.6^{*}$ & $-4.0^{*}$ & $-8.2^{*}$ & $-10.4^{*}$ & $21.0^{*}$ & $3.7^{*}$ \\
\hline $\begin{array}{l}\text { Pica- } \\
\text { Tarapacá }\end{array}$ & Inland & Pica 8 & P8 B0449 & $M$ & rib & $\begin{array}{l}\text { Sector } \\
\text { G }\end{array}$ & - & - & -4.4 & -6.2 & -9.5 & 13.3 & 3.5 \\
\hline $\begin{array}{l}\text { Pica- } \\
\text { Tarapacá }\end{array}$ & Inland & Pica 8 & P8 B0451 & $F$ & Skull & $\begin{array}{l}\text { Sector } \\
\text { E }\end{array}$ & - & - & -3.9 & - & -8.7 & 17.3 & 3.3 \\
\hline $\begin{array}{l}\text { Pica- } \\
\text { Tarapacá }\end{array}$ & Inland & Pica 8 & P8 B0453 & $F$ & $\mathrm{M}^{3}, \mathrm{Rib}$ & Sector I & $-11.1^{*}$ & $-11.0^{*}$ & $-7.4^{*}$ & $-9.2^{*}$ & $-12.0^{*}$ & $20.5^{\star}$ & $3.6^{*}$ \\
\hline $\begin{array}{l}\text { Pica- } \\
\text { Tarapacá }\end{array}$ & Inland & Pica 8 & P8 B0455 & $M$ & Rib & Sector I & - & - & -3.6 & - & -7.9 & 22.0 & 3.3 \\
\hline $\begin{array}{l}\text { Pica- } \\
\text { Tarapacá }\end{array}$ & Inland & Pica 8 & P8 B0463 & $\mathrm{F}$ & $\mathrm{M}^{3}, \mathrm{Rib}$ & $\begin{array}{l}\text { Sector } \\
\text { G }\end{array}$ & $-2.7^{*}$ & $-8.2^{*}$ & $-4.6^{*}$ & $-7.6^{*}$ & $-10.0^{*}$ & $13.2^{*}$ & $3.2^{*}$ \\
\hline $\begin{array}{l}\text { Pica- } \\
\text { Tarapacá }\end{array}$ & Inland & Pica 8 & P8 B0466 & $M$ & Rib & - & - & - & $-5.1^{*}$ & $-8.2^{*}$ & $-10.0^{*}$ & $14.2^{*}$ & $3.5^{*}$ \\
\hline $\begin{array}{l}\text { Pica- } \\
\text { Tarapacá }\end{array}$ & Inland & Pica 8 & P8 B0467 & $M$ & Rib & $\begin{array}{l}\text { Sector } \\
\text { D }\end{array}$ & - & - & $-3.9^{*}$ & $-7.5^{*}$ & $-10.6^{*}$ & $13.4^{*}$ & $3.7^{*}$ \\
\hline $\begin{array}{l}\text { Pica- } \\
\text { Tarapacá }\end{array}$ & Inland & Pica 8 & P8 B0468 & $F$ & $\mathrm{M}^{2}, \mathrm{Rib}$ & Sector I & $-3.0^{*}$ & $-7.6^{*}$ & $-4.0^{*}$ & $-8.0^{*}$ & $-9.0^{*}$ & $21.5^{*}$ & $3.4^{*}$ \\
\hline $\begin{array}{l}\text { Pica- } \\
\text { Tarapacá }\end{array}$ & Inland & Pica 8 & P8 B0469 & $M$ & Rib & - & - & - & $-4.1^{*}$ & $-8.5^{\star}$ & $-8.8^{*}$ & $21.5^{*}$ & $3.4^{*}$ \\
\hline $\begin{array}{l}\text { Pica- } \\
\text { Tarapacá }\end{array}$ & Inland & Pica 8 & P8 B0470 & $F$ & Rib & $\begin{array}{l}\text { Sector } \\
\text { D }\end{array}$ & - & - & $-4.7^{*}$ & $-8.4^{*}$ & $-10.5^{*}$ & $14.2^{*}$ & $3.5^{*}$ \\
\hline $\begin{array}{l}\text { Pica- } \\
\text { Tarapacá }\end{array}$ & Inland & Pica 8 & P8 B0476 & $M$ & $\mathrm{M}^{2}, \mathrm{Rib}$ & $\begin{array}{l}\text { Sector } \\
\text { G }\end{array}$ & -4.8 & -11.0 & -4.4 & -7.8 & -10.1 & 24.1 & 3.3 \\
\hline $\begin{array}{l}\text { Pica- } \\
\text { Tarapacá }\end{array}$ & Inland & Pica 8 & P8 B0478 & $\mathrm{F}$ & $\mathrm{PM}_{1}, \mathrm{Rib}$ & $\begin{array}{l}\text { No } \\
\text { referen } \\
\text { ce }\end{array}$ & -9.0 & -7.8 & -11.1 & -5.1 & -12.3 & 24.2 & 3.4 \\
\hline $\begin{array}{l}\text { Pica- } \\
\text { Tarapacá }\end{array}$ & Inland & Pica 8 & P8 B0483 & $F$ & $\mathrm{M}_{3}$, Rib & $\begin{array}{l}\text { Sector } \\
\text { G }\end{array}$ & $-2.2^{*}$ & $-9.2^{*}$ & $-8.5^{*}$ & $-6.3^{*}$ & $-13.3^{*}$ & $20.3^{*}$ & $3.2^{*}$ \\
\hline $\begin{array}{l}\text { Pica- } \\
\text { Tarapacá }\end{array}$ & Inland & Pica 8 & P8 B0484 & $\mathrm{F}$ & Rib & $\begin{array}{l}\text { Sector } \\
\text { A }\end{array}$ & - & - & $-4.8^{*}$ & $-8.8^{*}$ & $-9.3^{*}$ & $16.6^{*}$ & $3.4^{*}$ \\
\hline $\begin{array}{l}\text { Pica- } \\
\text { Tarapacá }\end{array}$ & Inland & Pica 8 & P8 B0492 & $\mathrm{U}$ & Rib & $\begin{array}{l}\text { Sector } \\
\text { D }\end{array}$ & - & - & $-11.7^{*}$ & $-10.1^{*}$ & $-16.9^{*}$ & $13.3^{*}$ & $3.7^{*}$ \\
\hline
\end{tabular}




\begin{tabular}{|c|c|c|c|c|c|c|c|c|c|c|c|c|c|}
\hline $\begin{array}{l}\text { Pica- } \\
\text { Tarapacá }\end{array}$ & Inland & Pica 8 & P8 B0493 & $M$ & $\mathrm{M}_{2}$, Rib & $\begin{array}{l}\text { Sector } \\
\text { G }\end{array}$ & -3 & -8.0 & $-6.0^{*}$ & $-8.9^{*}$ & $-9.9^{*}$ & $14.2^{*}$ & $3.3^{*}$ \\
\hline $\begin{array}{l}\text { Pica- } \\
\text { Tarapacá }\end{array}$ & Inland & Pica 8 & P8 B0498 & $\mathrm{U}$ & Rib & $\begin{array}{l}\text { Sector } \\
\text { D }\end{array}$ & - & - & -8.7 & -5.2 & -10.3 & 20.3 & 3.5 \\
\hline
\end{tabular}

Table 1. Carbon, nitrogen and oxygen stable isotope values from bone and teeth for different sites associated with the Antofagasta, Loa-San Pedro, Tarapacá Coast and Tarapacá Inland (Pica-Tarapacá). Sex is indicated as F, Female; M, Male; and U, Unknown. Samples with poor collagen preservation are indicated in italics for the $\mathrm{C} / \mathrm{N}$ ratios. All individuals sampled here are from adults. Previously published samples are indicated with an asterisk $\left(^{*}\right)$ (Santana-Sagredo et al. 2015). 


\begin{tabular}{|c|c|c|c|c|c|c|c|c|c|c|c|c|c|c|c|c|c|c|c|c|}
\hline \multirow{2}{*}{ Stable Isotope } & \multicolumn{5}{|c|}{ Antofagasta } & \multicolumn{5}{|c|}{ Loa-San Pedro } & \multicolumn{5}{|c|}{ Tarapacá Coast } & \multicolumn{5}{|c|}{ Tarapacá Inland } \\
\hline & $n$ & Mean & SD & $\operatorname{Max}$ & Min & $\mathrm{n}$ & Mean & SD & $\operatorname{Max}$ & Min & $\mathrm{n}$ & Mean & SD & $\operatorname{Max}$ & Min & $\mathrm{n}$ & Mean & SD & $\operatorname{Max}$ & Min \\
\hline$\delta^{13} \mathrm{C}$ enamel & 1 & -9.2 & 0.0 & -9.2 & -9.2 & 10 & -7.1 & 2.3 & -2.1 & -9.8 & 7 & -7.2 & 3.0 & -3.0 & $\begin{array}{c}-12.9 \\
\end{array}$ & 21 & -5.0 & 3.5 & -0.6 & -11.5 \\
\hline$\delta^{18} \mathrm{O}$ enamel & 1 & -5.8 & 0.0 & -5.8 & -5.8 & 10 & -6.2 & 1.1 & -4.6 & -8.1 & 7 & -7.7 & 1.1 & -6.0 & -9.0 & 21 & -8.6 & 1.7 & -3.7 & -11.3 \\
\hline $\begin{array}{l}\delta^{13} \mathrm{C} \text { bone } \\
\text { apatite }\end{array}$ & 5 & -8.0 & 0.8 & -6.7 & -8.8 & 37 & -8.9 & 1.1 & -6.3 & -11.6 & 10 & -9.6 & 1.3 & -6.5 & -11.1 & 45 & -6.0 & 2.6 & -3.6 & -13.0 \\
\hline $\begin{array}{l}\delta^{18} \mathrm{O} \text { bone } \\
\text { apatite }\end{array}$ & 5 & -1.4 & 0.8 & -0.3 & -2.3 & 37 & -3.9 & 0.9 & -2.2 & -7.6 & 10 & -5.3 & 1.8 & -3.1 & -9.7 & 41 & -7.6 & 1.4 & -4.1 & -10.1 \\
\hline$\delta^{13} \mathrm{C}$ collagen & 5 & -11.7 & 0.4 & -11.3 & -12.1 & 34 & -14.3 & 1.2 & -11.6 & -17.4 & 10 & -11.5 & 1.3 & -9.2 & -13.7 & 45 & -11.0 & 2.5 & -7.9 & -18.6 \\
\hline $\begin{array}{l}\delta^{15} \mathrm{~N} \\
\text { collagen }\end{array}$ & 5 & 25.5 & 0.6 & 26.1 & 24.6 & 34 & 11.5 & 1.5 & 15.4 & 7.3 & 10 & 25.5 & 1.6 & 27.4 & 21.9 & 45 & 17.7 & 4.2 & 27.4 & 10.9 \\
\hline
\end{tabular}

Table 2. Descriptive statistics of $\delta^{13} \mathrm{C}, \delta^{15} \mathrm{~N}$ and $\delta^{18} \mathrm{O}$ from bone collagen, apatite and tooth enamel for the Antofagasta, Loa-San Pedro, Tarapacá Coast and Tarapacá Inland cultural groups. 